\title{
2 The Province of Tripoli and its Significance for German Interests (1870-1884)
}

This chapter highlights the geographical, strategic and economic significance of the province of Tripoli to Germany from 1870 to 1884 . Like many other parts of the Arab world the province of Tripoli was under the rule of the Ottoman Empire during this period. Tripoli integrated Ottoman Empire when Suleiman I (1494-1566) was the sultan and Sinan Pasha (1506-1596) ruled this new region of the Empire in $1551,{ }^{1}$ expelling the Spanish from Tripoli. ${ }^{2}$ The period from 1551 to 1711 is known as a 'direct Ottoman rule'3 and was followed by a dynasty called al-Käramanlī between 1711 and $1835 .{ }^{4}$ This time is seen as independent or more autonomous from the central power in Istanbul. ${ }^{5}$ The Ottomans eliminated this dynasty and restored their direct control over the province in 1835. The following period, known as "the second Ottoman period"6 lasted until 1911, when the province was occupied by Italy. As the $19^{\text {th }}$ century approached its final quarter, rule in Libya was increasingly determined by world powers such as Britain, France and after 1871, Germany, meaning it was probably determined

1 Pasha is a Turkish title given to honor some governors with military ranks in the Ottoman Empire and it was given to the governors of the Ottoman provinces, Șabān, Suhail, al-Mu 'jam al-mausu'i li-l-mștalahat al- 'ūthmānīyyā al-tārīkhiyya, al-Riyyad, 2000, p. 52.

2 Ibn Ghalbūn al-Ṭarābulsī, Abū 'Abd al-llāh Moḥammad bin Khalīl, al-Tadhkār fĩ man malak Ṭarābulis wa mā kān bihā min Akhbār, șaḥhahahahu al-Ṭāhir Aḥmed al-Zāwī, Dār al-madār alislāmī, Bayrūt, 2004, p. 160; see also Brogini, Anne and Maria Ghazali, "Un enjeu espagnol en Méditerranée: les présides de Tripoli et de La Goulette au XVIème siècle”, Cahiers de la Méditerranée, 70-1, 2005, pp. 9-43 and for a larger discussion on the debate see also Özbaran, Salih, The Ottoman Response to European Expansion, Isis, Istanbul, 1994; Inalcik, Halil, An Economic and Social History of the Ottoman Empire, CUP, Cambridge, 1994.

3 See for example the work of Mütevelli, el-Feth, Ahmed Fuad, al-Osmani li el-Şam ve Misır ve mukaddimat min vaka el-vasaik, dar el-nahda el-misriyya, Cairo, 1976, For the debate on the autonomy of Ottoman provinces see Lafi, Nora, Rattachement et autonomie locale: réflexions sur la ville Ottomane, in Villes rattachées, ed. by Denise Turrel et al., Presses universitaires François Rabelais, Tours, 2003, pp. 99-112.

4 The name comes from the Karman region in southern Anatolia. This was the origin of their grandfather and they belong to the class called al-Kuarglah. Ibn Ghalbūn, al-Tadhkär fì man malak Țarābulis, p. 275; see also Micacchi, Rodolfo, La Tripolitania sotto il dominio dei Caramanli, A. Airoldi, Intra, 1936.

5 al-Kīb, Najm al-Dīn Ghālib, Madīnat Ṭarābulis 'abr al-tārīkh, al-Dār al-'arabiyya li-alkitāb, Țarābulis - Tūnis, 1978, p. 74.

6 Bruce St. John, Ronald, Libya: Continuity and Change, Routledge, 2011, p. 11; Ibn Mūsā, alMujtama' al 'arabī al-lībī fì al-' ahd al- 'ūthmānī, al-Dār al-'arabiyya li-l-kitāb, Ṭarābulis, 1988, p. 26. 
by changing relationships between the Ottoman administration in Istanbul and the African provinces like the province of Tripoli. ${ }^{7}$

It is noteworthy that the significance of the province of Tripoli to the Europeans, including Germany, did not begin in the period under study (1870-1884), but can be seen going back to the Middle Ages, when North Africa was under the continuous threats of Islamic-Christian disputes and wars started in or ended by Spain. ${ }^{8}$ Other authors state that the importance of the province was linked to the establishment of the three cities on the coast, which are Oya (Tripoli), Sabratha and Leptis, in the late $6^{\text {th }}$ century BC, and which thus go back even further in time. ${ }^{9}$ However, I argue that it was specifically the Industrial Revolution in Europe and the spread of colonialism and imperialism in North Africa that caused Tripoli to acquire a key relevance for the access that it offered to different parts of Africa. The ideal location and its ports played a major role in the history of the province in enhancing trade both internally and externally, as it represented a secure and practical port for trade. Tripoli also played a significant role in the wars and conflicts in the Mediterranean. The province of Tripoli was active in most of the political events that took place in the Mediterranean since the $16^{\text {th }}$ century. ${ }^{10}$ This is mainly because Tripoli and its ports were located in the middle of the Mediterranean and any power seeking to dominate the eastern, western, or internal parts of Africa would take Tripoli as its starting point. Thus, Tripoli's strategic importance based on the access to different parts of Africa and the connection of these regions to the European continent and to North America. The province of Tripoli was therefore important for the Ottoman administration and was a crucial place to defend. ${ }^{11}$ In addition, caravan trade routes existed in the province. Increasingly it attracted the attention of many European powers as they competed with the Ottomans at the time of the Ottoman reforms called Tanzīmāt, starting in $1839 .{ }^{12}$ The Europeans viewed the whole region as important for enhancing their trade with Africa.

7 Deringil, Selim, “'They live in a State of nomadism and savagery”: The late Ottoman Empire and the post-colonial debate", Comparative Studies in Society and History, 45-2, 2003, pp. 311342; and his book The Well-Protected Domains. Ideology and the Limitation of the Power in the Ottoman Empire 1876-1909, London and Oxford, 1998.

8 See for example: Koloğlu, 500 Years in Turkish-Libyan Relations, pp. 11-15.

9 al-Kīb, Madīnat Tarābulis 'abr al-tārīkh, p. 14.

10 Alghafal, Suaad, al- 'Ālāqāt al-lībiyyā al-tūnīsīyya khilāl al-'ahd al-'ūthmānī al-thānī (18351911), markaz jihād al-lībīyyīn li-l-dirāsāt al-tārīkhiyya, Ṭarābulis, 2006, p. 10.

11 Lafi, Nora, "L'empire Ottoman en Afrique, perspectives d'histoire critique”, Cahiers d'Histoire. Revue d'Histoire Critique, 2015, 128, pp. 59-70.

12 On this previous trade, see numerous studies like Wright, John, "Sequins, slaves and Senna: Tripoli’s international trade in 1767”, Africa: Rivista Trimestrale Di Studi e Documentazione 


\subsection{The Province of Tripoli: A Colonial Bridgehead to Africa?}

Tripoli was referred to by a number of names over the centuries. ${ }^{13}$ The Greeks had dubbed it "Libyas", a name which referred to the area on the western border of Egypt. ${ }^{14}$ This name appears to be derived from the word Lippo, which was the name of the tribes living in the region. The Romans referred to it as Africa, and this term was used for the region of North Africa as a whole. ${ }^{15}$ It began to be called Tripoli in the third century. ${ }^{16}$ Then it came to be known as Tripolitania, which then was changed to Tribols. Under Ottoman rule, this province was first called Eyālet Tarābulis al-Ghārb in 1835, and then changed to Wilāyāt Tarābulis al-Ghārb, which means province of Tripoli, in $1865 .{ }^{17}$ The city of Tripoli became the capital of the province. ${ }^{18}$ It is worth mentioning that in the German documents it is referring to as Tripolitania. The name Libya was first used after the Italian occupation in 1911. ${ }^{19}$ Herodotus mentioned the names of some tribes who lived in Tripoli during the $15^{\text {th }}$ century BC, including the Nasamoin, Garamanti, Macae and Paylli. ${ }^{20}$ Most of them were concentrated in coastal areas, which provided them with different livelihood options. They were also concentrated around internal

Dell'Istituto Italiano per l'Africa e l'Oriente, 63-2, 2008, pp. 249-260; J.C. Zeltner, Tripoli, carrefour de l'Europe et des pays du Tchad, 1500-1795, L'Hamattan, Paris, 1992; Fisher, Allan G. B. and Humphrey J. Fisher, Slavery and Muslim Society in Africa: The Institution in Saharan and Sudanic Africa and the Trans-Saharan Trade, C. Hurstand Co., London, 1970; and Panzac, Daniel, "Le commerce maritime de Tripoli de Barbarie dans la seconde moitié du XVIIIème siècle”, Revue d'Histoire Maghrebine, 69-70, 1993, pp. 141-167; and Panzac, Daniel, "Une activité en trompel'oeil: la guerre de course à Tripoli de Barbarie dans la seconde moitié du XVIIIème siècle”, R.E.M.M.M, 47-1 1988, pp. 126-141; Gemery, Henry A., Jan S. Hogendorn, The Uncommon Market: Essays in the Economic History of the Atlantic Slave Trade, Academic Press, New York, 1979.

13 See Riemer, Michael J., Colonial Bridgehead 1807-1882, Westview Press, Boulder Colorado, 1997, p. 251.

14 See Zimmermann, Klaus, Libyen: das Land südlich des Mittelmeers im Weltbild der Griechen, C.H. Beck, Munich, 1999.

15 For a discussion on the Roman period, see Jerary, M. Tahar, "Septimius Severus the Roman emperor, 193-211 AD”, Africa: Rivista Trimestrale Di Studi e Documentazione Dell Istituto Italiano per l'Africa e l'Oriente, 63-2, 2008, pp. 173-185.

16 See for this point the studies of Salvatore Bono, op.cit. and Cresti, Federico, La Libya tra Mediterraneo e mondo islamico, Giuffrè, Milano, 2006.

17 For this point see Günes, Isiksel, La diplomatie Ottomane sous le règne de Selim II: paramètres et périmètres de l'Empire Ottoman dans le troisième quart du XVIème siècle, Peeters, Paris, 2016. 18 Rūsi, Itūri (E. Rossi), Lībiyā mundhu al-fath al 'arabì ḥatā sanat 1911, translated with an introduction by Khalīfa Moḥammad al-Tilīsī, Dār al-thaqāfā, Bayrūt, 1974, pp. $23-25$.

19 "Libya" will be used when discussing the period starting with the Italian occupation in 1911. 20 Fage, John D., "The Libyans", The Cambridge History of Africa: From c. 500 BC to AD 1050, vol. II, Cambridge University Press, Cambridge, 1978. 
oases with wells and springs. The most important of these oases were Jalu and al-Kufra, Ghat and Awjilah that connected the northern part of Libya and the African greatest Sahara. A third center of population concentration were the cities in the south of the province, which represented a north-south axis. These cities were marked as centers of trade and represented meeting points for the groups of traders en route to Africa, or coming from Africa toward the city of Tripoli, the province of Tunisia or elsewhere. Tripoli shared an eastern border with Egypt and a western border with Tunisia and Algeria ${ }^{21}$ (see Appendix 3). The southern border, with sub-Saharan Africa (the region now known as SudanChad-Niger) also made the province a good entry point into the rest of the continent. ${ }^{22}$ In addition to its land borders, the coastal borders of Tripoli were also of strategic relevance. Its coastline, which stretches north along the Mediterranean for over $1.900 \mathrm{~km}$, attracted the attention of both the Ottomans and Europeans. ${ }^{23}$ It was considered the starting point to different directions. In the south of the province, the border with Africa is almost $2.000 \mathrm{~km} .{ }^{24}$ The province of Tripoli can thus be seen to occupy a large geographical area, containing varied geographical and climatic differences within it. ${ }^{25}$ However, the province of Tripoli is dominated by a Mediterranean climate, with cool winters and hot summers. ${ }^{26}$ Moreover, the province of Tripoli is divided into plain areas, mountainous areas and coastal areas, and other desert and semi-desert areas. ${ }^{27}$ There are no natural rivers but there are many valleys including Wadi al-Shati and al-Sayal and a large number of oases. Its geographical location led the province of Tripoli to play a major regional role in a number of different historical periods. The importance of Tripoli is

21 al-Jawharī, Yusrī 'Abd al-Razzāq, Shamāl Afrīqiyā dirāsā fĩ al-jughrāfīyya al-Tārīkhiyya, Dār al-Ma'ārif, al-Qāhira, 1978, p.15.

22 al-Sāqizlī, 'Abd al-Lațīf Sulaymān, Lībiyā al-thawrā, vol. 1, Dār Mimfīs li-l-țibā'a wa al-nashr, al-Qāhira, 1398 H, p. 9.

23 Tūllī, Rītshārd (Richard Tully), 'Ashar sanawāt fī bilāt Țarābulis, translated by 'Umar alDīrāwī Abūhijla, maktabat al-Furjānī, Ṭarābulis, n.d., p. 8.

24 See for example Zimmermann, Libyen: das Land südlich des Mittelmeers im Weltbild der Griechen, Munich, 1999. See as well Abū Shārib, Moḥammad'Alī, "Tijārat al-qawāfil wa 'alāqatuhā bi-wāḥat Awjilah”, Awjilah baina al-māḍī wa al-ḥạdir (1950-1951), a'māl al-nadwā al- 'ilmiyya alsābi 'a allatī 'uqidat bī-madīnat Awjilah (17-20/9/2009), ed. by Moḥammad Bashīr Suwīsī, markaz jihād al-lībìyyīn li-l-dirāsāt al-tārīkhiyya, Țarābulis, 2007, p. 131.

25 Nājī, Maḥmūd, Tārīkh Ṭarābulis al-ghārb, translated by 'Abd al-Salām Adham wa Moḥammad al-'Usțā, al-jāmi'a al-lībiyyā, kulīyyāt al-'ādāb, Ṭarābulis, n.d., p. 13.

26 Dardano, Achille and Riccardo Riccardi, Atlante D’Africa, Ulrico Hoepli Editore, Milano 1936, xiv. 27 Brūshīn, N.A., Tārīkh Lībiyā min nihāyāt al-qarn al-tāsi' 'ashar, ḥata 'am 1969, translated by 'Imād Ḥātim, revised by Mīlād al-Magrahị, markaz jihād al-lībīyyīn ḍid al-ghazū al-iṭāī, Ṭarābulis, 1988, pp. 25-26. 
evident since the establishment of the three cities of Oea (Tripoli), Sabratha and Leptis along the coast in the late $6^{\text {th }}$ century $\mathrm{BC} .{ }^{28}$ The focus was initially on the city of Tripoli, which later became the capital of the province. However, other cities were also significant, including Benghazi, located in the eastern coastal region, and Murzuq, located in the southof the province, ${ }^{29}$ while Sawkanh and Ghadames were centrally located, so the different directions were connected to each other (see map 1). Over a long period, the province of Tripoli had attracted the attention of the Phoenicians and Romans, Spanish, Greek, Arab and Islamic cultures and the Ottoman Turks specifically, who selected Tripoli as their military base in North Africa when they ruled the region. Its location also attracted the attention of the European powers for the access that it offered to many important areas. The province of Tripoli was thus incorporated into their strategic plans and actions. $^{30}$ Tripoli thus clearly functioned as a bridge between the Mediterranean and sub-Saharan countries such as western and central Sudan and the rest of the African kingdoms, which increased the geographical significance of the province. This is due to its open frontiers with the desert. There were no natural obstacles that impeded contact between these countries. Ottoman Tripoli was one of the most important naval bases in the Mediterranean. ${ }^{31}$ It was used by the Ottoman naval service to attack Malta in $1565,^{32} 1703,1705$ and $1709^{33}$ and to control the Mediterranean Sea. Tripoli also contributed to the restoration of the Tunisian territory that was under Spanish rule. The war with the Spanish began in $1559^{34}$ and continued until the end of their colonial rule. In 1581, the Spanish signed an agreement ${ }^{35}$ acknowledging Ottoman sovereignty over Tunisia. Moreover, it is not possible to ignore the role played by the Tripolitanian marines, especially in the aftermath of the Battle of Lepanto in 1571, when the Ottomans reasserted their

28 al-Kīb, Madīnat Țarābulis 'abr al-tārīkh, p. 14.

29 Sharaf al-Dīn, In'ām Moḥammad, Madkhal ilā tārīkh Ṭarābulis al-ijtimā'ì wa al-iqtiṣādī: dirāsa fī mu'assāt al-mādīna al-tijāriyya, markaz jihād al-lībīyyīn li-l-dirāsāt al-tārīkhiyya, Tarābulis, 1998, p. 23.

30 On this point see Orhan Koloğlu, op.cit.

31 Panzac, Daniel, La marine Ottomane, de l'apogée à la chute de l'Empire (1572-1923), CNRS Editions, Paris, 2009.

32 Nājī, Tärīkh Ṭarābulis al-ghārb, p. 167.

33 Rūsi, Lībiyā mundhu al-fatḥ al'arabì ḥatā sanat 1911; see also Panzac, Daniel, Commerce et navigation dans l'Empire ottoman au XVIIIe siècle, Isis: Istanbul, 1996.

34 al-Zāwī, al-Ṭāhir Aḥmed, Wulāt Ṭarābulis al-ghārb min al-fatḥ al-'arabī ilā nihāyat al- 'ahd alturkī, Dār al-fatḥ li-l-țibā'a wa al-nashr, Bayrūt, wa al-Sayyid Moḥammad al-Ramāḥ Bashīna, Ṭarābulis, 1970, p. 265.

35 Rāfiq, 'Abd al-Karīm, al- 'Arab wa al-'ūthmānīyyūn, 1516-1916, Dimashq, 1974, p. 79. 
sovereignty - after their defeat at Lepanto - in the Eastern Mediterranean. ${ }^{36}$ In 1667, the Tripolitanian naval forces were under the direct authority of the Ottoman Pasha as they were part of the Ottoman military forces in Tripoli. It is noteworthy that the Europeans in general possessed relatively little information about the importance and size of interior and central Africa in the first half of the $18^{\text {th }}$ century compared with the extent of their information about the African coasts. They were therefore eager to get information about these areas. Tripoli, in their view, was the appropriate port for exploring the internal parts of Africa. It also seems that the ease of communication between the ports of the south and the northern Mediterranean, especially Sicily and the Italian ports, with the ports of the province of Tripoli, such as the city of Tripoli, Zuwarah, Misurata and Benghazi, boosted the province's strategic importance ${ }^{37}$ Moreover, it is obvious that the strategic importance of the province of Tripoli was one of the main reasons that prompted the Italians to seek control of the province, a goal that they attained in 1911. However, the realization of this goal took place after thorough political, economic and cultural preparation of the ground during of Ottoman rule. ${ }^{38}$ France also focused on the city of Tripoli and began to work in the south of the province, specifically in the city of Ghadames on the border with the Ottoman province of Algeria in $1826 .{ }^{39}$ France convinced the Ottoman authority to establish a consular agency in Ghadames, after they had already obtained a consular agency in the city of Tripoli. The French had essentially begun to negotiate with tribal leaders to convince them to sign an agreement. The main terms of the agreement were about trade and taxes to be paid by the caravan convoys that passed through Ghadames. The agreement was signed in the city of Ghadames in $1860 .{ }^{40}$ This struggle of the French to find a foothold in the province of Tripoli was due to its geo-political and

36 al-Tilīsī, Khalīfa Moḥammad, Ḥikāyāt madīnat Ṭarābulis ladā al-raḥḥāla al-'arab wa alajānib, al-Dār al-'arabiyya li-lkitāb, Lībiyā-Tūnis, n.d., p. 70.

37 See for example Hoefer, Ferdinand, “Etats Tripolitains: régence de Tripoli”, in L'Univers Pittoresques, 1856; see as well F. Coro translated in Arabic: Kūrū, Frānshiskū, Lībiyā athnā' al- 'ahd al 'ūthmānī al-thānī, translated by Khalīfa al-Tilīsī, al-munsha'a al-'āmmā li-l- nashir wa al-tawzi wa al-i'lān, Ṭarābulis, 1984, pp. 59, 139.

38 Ruhūmā, Mușțafa Ḥāmid, al-Muqāwama al-lībiyyā al-turkīyya dịd al-ghazū al-ițālī Uktūbar 1911-Uktūbar 1912, markaz jihād al-lībīyyīn ḍid al-ghazū al-ițāīi, Țarābulis, 1988, p. 24.

39 Lafi, Nora, “Ghadames cite-oasis entre empire ottoman et colonialisme”, in Libia tra Mediterraneo e mondo islamico, ed. by Frederico Cresti et al., 2006, pp. 55-70.

40 al-Ḥindīīi, Sa'īd 'Abd al-Raḥmān, "Tațawwur tijārat al-qawāfil fī wilāyāt Ṭarābulis alghārb(1835-1911)”, al-Mujtama ' al-lībī (1835-1950), a'māl al-nadwa al-'ilmiyya al-thāmina allatī 'uqidat bi-l-markaz fī al-fatra min 6-27/9/2002, ed. by Moḥammad al-Ṭāhir al-Jarārī, markaz jihād al-lībīyyīn li-l-dirāsāt al-tārīkhiyya, Țarābulis, 2005, p. 969. 
military importance and to the economic benefits that arose from this. ${ }^{41}$ The French recognized the great services that could be provided by the city of Ghadames if it was under their authority. They saw Ghadames as a connection to their colonies in Tunisia and Algeria, using the trade routes on which the city was situated. They also realized its considerable economic significance, which will be explained later in this chapter when discussing the role of cities in boosting trade in the province. France obtained official permission from the Ottoman Government in 1842 and 1843 to open the consulates in Murzuq and Ghadames. ${ }^{42}$ These consulates were used to directly supervise trade heading to or coming from sub-Saharan Africa. ${ }^{43}$ The candidate for the position of consul was Eugene Ricard, the French consul in Malta. What distinguished him from the other candidates was that he knew the customs and traditions of the place, since he had previously lived in Benghazi, as well as the fact that he was fluent in Arabic. ${ }^{44}$ Through this, the French had significantly strengthened their position by 1894 . France was not the only country to establish a consulate in Ghadames; other European countries such as Britain also maintained a representative office in this region. Furthermore, Tobruk represented an important city for the Germans because it could be used as a port to inner Africa and to reach the southern Nile bank. From there, they could move freely between their colonies in West and East Africa, at the same time avoiding direct contact with Britain, which was already in Egypt, Sudan, and controled the main ports, land and sea lanes there. Britain also had the strongest European fleet. The British felt the increasing presence of German influence in the region as the Germans were persistently strengthening their relations with the Sultan of the Arab Maghreb, as well as augmenting their trade activities and projects. The German efforts resulted in gaining the privilege of building the port of Tangier in Morocco, and their economic activities extended to both Algeria and Tunisia despite the fact that these regions were under the

41 For an overview of the economy and Ottoman empire see e.g. İslamoğlu-İnan, Huri (ed.), The Ottoman Empire and the World Economy, Cambridge University Press, Cambridge, 1987, and see also the seminal work of Halil İnalcik and particularly İnalcik, Halil and Donald Quataert (eds.) An Economic and Social History of the Ottoman Empire 1300-1914, Cambridge University Press, 1994.

42 The British consul had also been represented in Tripoli since the $17^{\text {th }}$ century. See Baker, Thomas and C.R. Pennell, Piracy and Diplomacy in Seventeenth Century North Africa, The Journal of Thomas Baker, English Consul in Tripoli, 1677-1685, Golden Cockerel Press, London, 1989.

43 al-Ḥindīrī, "Tațawwur tijārat al-qawāfil fĩ wilāyāt Ṭarābulis”, p. 969.

44 Politisches Archiv des Auswärtigen Amts, Allgemeine Angelegenheiten von Tripolis, Das Kaiserliche Konsulat in Tripoli Bd. 1, 1895 bis 1899, R16111. 
control of France..$^{45}$ A report compiled by Friedrich Gerhard Rohlfs (April 14, 1831 - June 2, 1896) highlighted the strategic importance of Tripoli. ${ }^{46}$ The study provided evidence that whoever controlled Tripoli could also rule Sudan. ${ }^{47}$ The same sentiments can be found in the discourse of European political actors around the same time, in addition to the reports of individual travelers.

Before being mentioned in reports, texts and studies conducted by the Germans, Tripoli was mentioned in different European accounts, such as the studies conducted by the French and the British. Separately, and in the context of international competition (given that the Tanzimāt reforms of the Ottoman Empire were largely introduced to respond to the challenges of European imperialism),$^{48}$ they all emphasized the strategic importance of the province of Tripoli for their economic and colonial goals first of all. ${ }^{49}$ There were also projects planned by some Europeans which reveal their interests in the region. For instance, the British envisaged integrating all the valleys in Tripoli and supplying them with water from the Mediterranean..$^{50}$ They hoped that this would create a new maritime route toward sub-Saharan Africa. The project was not implemented because it was very expensive and believed to be unrealistic. France had also offered to build a canal to link the city of Gabès in Tunisia with Tripoli, but they retreated from this proposal as well..$^{51}$ Nevertheless, France did not abandon its economic relations with Tripoli and continued to take advantage of the vital trade routes in Tripoli in the hope of connecting the south of

45 Muḥ̄azaẓa, 'Alī, Mawāqif al-duwal al-kubrā min al-waḥdā al- 'arabiyya (1): mauqaf Faransā wa 'Almāniya wa Ițalìya min al-waḥdā al-' 'arabiyya 1919-1945, markaz dirāsāt al-waḥdā al-'arabiyya, Bayrūt, n.d., pp. 23-24.

46 On Rohlfs' occupation and work see the introduction to this study.

47 Nājī, Tārīkh Tarābulis al-ghārb, p. 78.

48 For this Tanzimāt (reforms) there is a very important historiography, for an overview on the Ottoman empire see for example Findley, Carter Vaughn, Ottoman Civil Officialdom: A Social History, Princeton University Press, Princeton, 1989; and Davison, Roderic H., Reform in the Ottoman Empire 1856-1876, Princeton University Press, Princeton, 1905; for an very interesting view on this period see also Fuhrmann, Malte, Der Traum vom deutschen Orient: Zwei Deutsche Kolonien im Osmanischen Reich 1851-1918, Campus, Frankfurt-New York, 2006 and Fuhrmann, Malte, Den Orient deutsch machen: Imperiale Diskurse des Kaiserreiches über das Osmanische Reich, 2002, For Tripoli see for example the study of Lafi, Nora, "Entre ottomanité, colonialisme et orientalisme: les racines ambiguës de la modernité urbaine dans les villes du Maghreb (1830-1960)", in Frankreich und Frankophonie: Kultur - Sprache - Medien, ed. by Sabine Bastian and Franck Trouilloud, Meidenbauer, Munich, 2009, pp. 143-162.

49 Nājī, Tārīkh Ṭarābulis al-ghārb, p. 78.

50 Ibid.

51 Ibid. 
the former Ottoman Algiers, colonized by France, and the region between present-day Mali and Chad, competing with the British in the south of the former Ottoman provinces of today's Sudan.

The natural climate of the province of Tripoli had a decisive effect on its economic options and opportunities. Harsh natural conditions like severe droughts, for example, limited agricultural potential. In addition, the province mainly depended on rainfall for the production of crops such as wheat and barley, as well as the cultivation of olive trees. ${ }^{52}$ This played a major role in guiding the population toward internal and foreign trade as an alternative to agriculture. Moreover, local people were taking advantage of the cities that represented trading focal points. The local people and the Ottoman governors were fully aware of the importance of trade for developing the economy of the province, as well as of the fact that its importance was increasing over time. This was apparent through the establishment of many trade centers and road networks used by convoys with significant economic uses; the result was a boom in internal trade. ${ }^{53}$ Cities like Tripoli, Benghazi, Sawkanh and Ghadames constituted the center of the economic activities. Routes like Tripoli-Kano (Nigeria), Tripoli-Borno, Tripoli-Benghazi, the middle route to Sudan and others played a significant role in enhancing trade between Tripoli, east, west and central Africa. Consequently, these routes enhanced the importance of the province to many internal and external powers including the Ottomans and the Europeans. ${ }^{54}$

\subsection{Political Situation and Administrative Structures between Natural Resources and Slave Trade}

From the restoration of direct Ottoman rule in 1835, prior to the period under study, the Ottoman Empire undertook a new approach in dealing with people of the province of Tripoli within the context of the administrative reforms referred to as Tanzimant. This was manifested in stricter control over Tripoli and more careful selection of its governors. The province came under the direct control of Istanbul, capital of the Ottoman Empire, and power was increasingly centralized, despite

52 Ḥamīda, 'Alī 'Abd al-Lațīf, al-Mujtama' wa al-dawlā wa al-isti'mār fī Lībiyā dirāsa fĩ al-ușūl al-ijtimā 'īyya wa al-iqtiṣādīyyā wa al-thaqāfiyya li-ḥarakāt wa siyāsāt al-tawāṭ̂' wa muqāwamat al-isti 'mār 1830-1932, markaz dirāsāt al-wahda al-‘arabiyya, Bayrūt, 1998, p. 78.

53 Ibid.

54 See Baker, Thomas and C.R. Pennell, Piracy and Diplomacy in Seventeenth Century North Africa. 
the attempts of local notables from cities and the hinterland to maintain control over their regions. In addition, some local leaders chose to work with France or Great Britain to strengthen their own influence, thereby also supporting the interests of these European powers through unrests or rebellions against the Ottoman Empire. ${ }^{55}$ This could, from a local perspective, have been seen as the rallying of external (European) support against imperial Ottoman rule. It was often the case at the time, at the cost of increased European influence, when more emphasis on local perspectives would have been useful. This context also helps to explain why the city of Tripoli remained the latest Ottoman provincial capital in North Africa, the residence of the Ottoman governor and the center of its administration.

The administrative structure was changed by the Ottomans repeatedly during this time under the frame of the Tanzimatat, or reform period. In 1835, Tripoli was an Eyālet (meaning large province) ${ }^{56}$ and the governor received the title of pasha. This Eyālet was later divided into administrative units called $q \bar{a}$ 'im maqāmiyya or sanjaks, with each of which governed by $q \bar{a}^{\prime} i m$ maqām (a governor). In 1865, this system was changed and the divisions of the Ottoman Empire were called provinces (wilāyāt). The internal administration in the province of Tripoli was structured as follows:

The province was divided into four sanjaks (sometimes called liwa $\bar{a}$ ), each of which contained a number of aqdìya (singular qad $\bar{a}^{\prime}$ ) with their own administrative center. A governor was selected for each sanjak..$^{57}$ The $q a d \bar{a}^{\prime}$ of Tripoli included the city of Tripoli and all the areas surrounding it, particularly in the west. The regions that it included were Tajura, Zanzur, and Jifarah. Other examples of aqdìya are Ujaylat, Zuwarah, Tarhuna, Warfalla, Gharyan, al-Aziziyah and al-Gosh. ${ }^{58}$ Qad $\bar{a}$ ' al-Khums included Sahel al-'Ahaamed, Taworgha, Meslata, Zlitan, Misurata and Sirte. ${ }^{59}$ Qaḍa $\bar{a}$ al-Jabal included Nawāḥ̄ like al-Haoud,

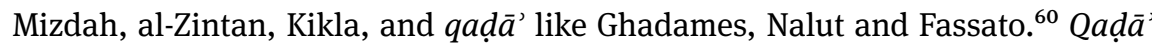
Fezzan, which was in the south of the province, included Murzuq, which was the capital of liwā' Sebha, and also included al-Wady al-Shargee, Jufrah, al-Shargya, al-Gatrun, Houn, Zillah, Sawkanh, al-Shati, Ghat, Taborshadh, and al-Ghayra. ${ }^{61}$ The status of the area of Barqa was unstable. It remained a $q \bar{a}$ 'im maqāmiyya under the control of the Ottoman government in the province of Tripoli from

55 Ibn Mūsā, al-Mujtama' al- 'arabī al-lībī, p. 18.

56 Rūsi, Lìbiyā mundhu al-fath al 'arabì, p. 384.

57 Kūrū, Lìbiyà athnā' al- 'ahd al- 'ūthmānī al-thānī, p. 26.

58 Rūsi, Lìbiyā mundhu al-fatḥ al 'arabì, p. 385; Nājī, Tārīkh Ṭarābulis al-ghārb, p. 85.

59 Rūsi, Lìbiyā mundhu al-fatḥ al 'arabì, p. 385.

60 See Nājī, Tārīkh Țarābulis al-ghārb, p. 85.

61 Rūsi, Lìbiyā mundhu al-fath al'arabì, p. 385. 
the beginning of Ottoman rule mainly because it was far from the center and lay in the region bordering Egypt. ${ }^{62}$ In 1836, Barqa was then transformed into a mutașarrîfìyya under direct control of Istanbul; this lasted until 1871, when it was returned to the control of the province of Tripoli. ${ }^{63}$ This only lasted for one year, when it again became a mutașarrifìy until 1888. Barqa was then divided into three qā'im maqāmiyya: Derna, Jalu and al-Marj and every sanjak was divided into Nawahī like the city of Tripoli. ${ }^{64}$

The structure of the society in the province of Tripoli was predominantly tribal. Each tribe was headed by a person called shaykh al-mahallah in small villages or in cities with a chief of the city (shaykh al-balad). ${ }^{65}$ This position was initiated at the time of the reforms in the province of Tripoli after the establishment of the new type of Ottoman municipality, al-baladiyya, in 1868 (the municipality of Tripoli). ${ }^{66}$ This position of shaykh al-mahallah or mukhtar with a chief of the municipality ( $r$ 'is al-baladiyya) and a council of the municipality (majlis al-baladiyya) was initiated in 1871. It was conceived as a new and modern municipality following the administrative system of the Ottomans. ${ }^{67}$ It represented an

62 Kūrū, Lìbiyā athnāa' al- 'ahd al- 'ūthmānī al-thānī, pp. 29-30; see also Lafi, Nora, L'Empire Ottoman en Afrique: perspectives d'histoire critique, 2015, 128, pp. 59-70.

63 Osmanli Belgelerinde: Trablusgarb (Țarābulis al-ghārb fĩ al-wathā'iq al-'ūthmāniyyā), Kemal Gurulkan, et.al, ed. by Salih Sadawi, Istanbul, 2013, p. 253

64 Kūrū, Lìbiyā athnā' al- 'ahd al- 'ūthmānī al-thānī, pp. 29-30.

65 For the quesion of shaykh al-balad in Ottoman cities and specifically Tripoli see the publications of Nora Lafi, op.cit., and those of Kūrū, Lìbiyā athnā' al- 'ahd al- 'ūthmānī al-thānī, p. 48-53. In other context and specifically tribe societies the cheikha existed as well and even with a very interesting gender aspect: "Si une femme est offensée par en homme qui lui aurait dit, par exemple qu'elle est laide, malpropre ou dévergondée, celle-ci se rend auprès de la cheikha du clan dont elle dépend, et porte une plainte contre qui a proféré ces offenses. La cheikha, après avoir consulté d'autres cheikhas de la tribu, détermine la peine à infliger à l'insultateur... Après la prononciation du verdict la cheikha accompagnée de 30 à 40 femmes se rendent devant le portail de l'accusé et au cours de toute la journée, parfois même la nuit, tapent du tambour pour l'obliger à s'exécuter...”, see the account of Pavel Chatev (1882-1953), a Bulgarian exiled in the region as a prisoner after his participation in the bombardment of the building of the Ottoman bank, symbol of European capitalism and the bombardment of the railway line of Salonika-Istanbul. This account was studied and published in Peev, Yordan, "Un exilé bulgare en Libye au début du XXème siècle”, Africa: Rivista Trimestrale Di Studi e Documentazione Dell'Istituto Italiano per l'Africa e l'Oriente, 63-2, 2008, pp. 283-295.

66 On the institutionalization of the new munipality in Tripoli see the work of Lafi, Nora, Une ville du Maghreb entre ancien régime et réformes ottomanes: genèse des institutions municipales à Tripoli (1795-1911), L'Harmattan, Paris, 2002.

67 See Baladiyyat Ṭarābulis fī mā'at 'ām 1286/1391H-1870/1970M, Dār al-ṭiba'a al-ḥadīthā, almațba'a al-lībiyyā Ṭarābulis, 1972, pp. 164-165 and Lafi, Nora, Municipalités méditerranéennes. 
institution between the population and the government in Tripoli and between the population and the central government in Istanbul. In villages, the person appointed had to have suitable qualifications and his authority was limited to the specific area (mahallah). A shaykh al-mahallah can be elected when the settlement had no fewer than 50 houses. The main responsibilities of the shaykh al-mahallah were mainly informing the population about orders (awamir), laws issued by the government. He also informed the government about events that took place in al-mahallah. ${ }^{68}$ Nonetheless, the Ottoman reform did not end the role of the shaykh al-mahallha, who continued to exercise local control after several conflicts. ${ }^{69}$ This was also the case in the central and southern parts of the province. Obviously, not all the governors who were sent to the province of Tripoli were of the same caliber. In addition to the varying levels of efficiency and political competence, some governors were also motivated by personal interests conflicting with those of the Empire. ${ }^{70}$ This was aggravated by the fact that governors were aware of the limited time for which they would hold their position, owing to the Ottoman policy of circumscribing the time that any individual governor spent in a single place. In addition, governors could also be removed or transferred at any point throughout their term in power. ${ }^{71}$ Transfers could result from complaints about the governor made by residents or cases of civil unrest. This became particularly clear in the latter half of the $19^{\text {th }}$ century. ${ }^{72}$ Local revolts challenged the new order and the Ottomans governors such as Mohammad Halit Pasha (1870-1871) or the shaykh al-balad'3 of Tripoli, 'Alī al-Qarqānī. ${ }^{74}$ 'Alī al-Qarqānī was assisted by two soldiers viewed as violators of the local traditions. ${ }^{75}$ The resi-

Les réformes urbaines Ottomanes au miroir d'une histoire comparée (Moyen-Orient, Maghreb, Europe méridionale), Klaus Schwarz, Berlin, 2005.

68 On this point see Lafi, Nora (ed.), Municipalités méditerranéennes.

69 Lafi, Nora, "L’affaire Ali al-Qarqânî, Tripoli 1872", in Etre notable au Maghreb: Dynamique des configurations notabiliaires, ed. by Abdelhamid Hénia and Ma'had al-Buhuth al-Maghribiyah al-Mu'asirah, Maisonneuve et Larose, Paris, 2006, pp. 201-214.

70 Kūrū, Lìbiyā athnā' al- 'ahd al- 'ūthmānì al-thānī, p. 26.

71 Lafi, “L'affaire ‘Alî al-Qarqânî, Tripoli 1872”, pp. 201-214.

72 See Lafi, Nora, "Petitions and accomodating urban change in the Ottoman Empire", in Istanbul as Seen from a Distance: Centre and Provinces in the Ottoman Empire, ed. by Elisabeth Özdalga, Saï Özervarli and Feryal Tansug, Istanbul, Swedish Research Institute in Istanbul, 2011, pp. 73-82. 73 Shaykh al-balad was a position given by the Ottomans to some of the original residents of Tripoli and had the tasks of communicating dirtectly with the local people. See Lafi, "L'affaire Ali al-Qarqani, Tripoli 1872".

74 Lafi, Nora, Une ville du Maghreb entre ancien régime et réformes ottomanes, op. cit, 2002, p. 146; 75 Baladiyyat Țarābulis fī māà 'à 'àm 1286/1391H - 1870/1970M, p. 161; Lafi, "L'affaire Ali alQarqani, Tripoli 1872", op.cit. 
dents of Tripoli made many complaints to the governor against al-Qarqān $\overline{\mathbf{i}}{ }^{76}$ and the negative effects of his policies on them, especially because he controlled everything in Tripoli including the industry. A revolt also broke out in the eastern part of the province, ${ }^{77}$ which prompted civil unrest throughout the province. The administrator equipped a military campaign to put the unrest down, although this was disbanded shortly afterwards as the unrest decreased. Mohammad Halit Pasha did not stay in power long. He was dismissed and replaced by Mohammad Rashid Pasha in 1871 in the context of growing European pressure in the region to control all Ottoman provinces. Mohammad Rashid Pasha implemented a moderate policy in Tripoli, balancing the demands of the Ottoman central government and a local Ottoman society in the face of European pressure. Therefore, they worked together to build good relations with many foreign consuls, including those of Britain, France, the United States, Tuscany (until 1866), Spain and others, which were competing for control over the Ottoman regions. Mohammad Rashid Pasha also introduced new reforms to different sectors in the province. However, this did not prevent the inhabitants of Fezzan in the south of the province from revolting and rejecting the authority of the Ottoman Empire. Laurent Charles Féraud (1829-1888), consul, spy and erudite who conducted research on this, indicated that the unrest was instigated by the Tuareg population in the far south of the province in 1871. At the same time, the tribes of Awlād Sulaymān in the central region also rejected Ottoman rule and their participation in the Tuareg revolution. ${ }^{78}$ The governor Mohammad Rashid Pasha tried to put this revolution down, ${ }^{79}$ particularly because it started to adversely affect trade convoys destined for the south of the province. It is noticeable that these disorders abated gradually with the outbreak of internal conflict between two Tuareg tribes, namely the al-Hāqar and 'Azqār tribes, on who had the authority over the southern part of the province. The conflict ended with the defeat of the 'Azqār tribe. This prompted Moḥammad 'Akhnūkhan, one leader of the'Azqār tribe in the southern part of

76 Lafi, Nora, Une ville du Maghreb entre ancien régime et réformes ottomane, op.cit, pp. 283-291.

77 Baladiyyat Țarābulis fī mãa'at' 'àm 1286/1391H - 1870/1970M, p. 163.

78 Fīru, Shāril (Féraud Charles), al-Hawlìyyāt al-lībiyyā mundhu al-fath al- 'arabī ḥattā al-ghazū al-iṭālī, translated by Moḥammad 'Abd al-Karīm al-Wāfi, jāmi 'āt Qāryūnis, Binghāzī, 1994, p. 504507. See also the introduction and the biography of this personnage by Lafi, Nora, Les annales tripolitaines de Charles Féraud, Paris, 2005, 437p; and Lafi, Nora, "Biographie: Laurent Charles Féraud, une passion coloniale”, in Laurent Charles Féraud: Peintre et témoin de la conquête de l'Algérie, ed. by Bernard Merlin, Editions Monelle Hayot, Saint-Remy-en-l'Eau, 2010; 112p., pp. 103-106.

79 Govenor or in Arabic Wãli is an administrative title that was used during the Caliphate and Ottoman Empire to designate governors of administrative divisions. 
Tripoli $^{80}$ to contact the Ottoman Government in Tripoli to seek protection in return for his submission to it. He later asked the Ottoman government to train and recruit new soldiers from among the local people to strengthen his power there. In the city of Ghat, also located in the south of the province of Tripoli, the situation was unstable until Mustafa Asim Pasha was appointed governor for nine months before leaving for the Yemenit Ottoman province in 1875. He decided that Ghat should be given the administrative status of a sanjak. He was able to regain control as part of his efforts to extend Ottoman authority of the province across the entire desert. He sent soldiers armed with cannons to strengthen the Ottoman presence and make it a district under the control of Fezzan. As part of these efforts Taborshada, which was located on the border with Chad, was also made a district of the province in $1881{ }^{81}$ Muștafa Asim Pasha gained an advantage over the other Ottoman governors in the province of Tripoli through his practice of travelling to see the conditions of the people in person, trying to address their problems before they become uncontrollable. ${ }^{82}$ Such outbreaks of civil unrest were frequently instrumentalized by British and French consuls and military interventions. The Berlin Conference in 1878 discussed and negotiated the distribution of political influence among European countries in the Ottoman world, whether in the Balkans or lands belonging to the Ottoman Empire in other regions..$^{83}$ It should be noted that the Ottoman Empire was aware of European ambitions in Tripoli, especially when France colonized Algeria and declared Tunisia a protectorate. The Ottoman Empire then considered the need to preserve its remaining Arab provinces. This was mainly done by preventing Tripoli from coming under the control of any European country. As a result, Ahmed Ezzat Pasha (1879-1881) was sent to Tripoli in 1879, where he attempted to introduce reforms to protect the province. His main work was to repair the forts and walls. ${ }^{84}$ This work was completed after him by Mohammad Nazif Pasha (1880-1881) who also focused on the defensive aspect by building many fortifications in the major centers around the city. They were equipped with cannons that were brought especially from the central government in Istanbul

80 Nājī, Tārīkh Ṭarābulis al-ghārb, p. 212.

81 Sāmiḥ, 'Azīz, al-'Atrāk al-'ūthmānīyyūn, fĩ Afrīqiyā al-shamāliyya, translated by 'Abd alSālām Adham, Dār al-Furjānī, al-Qāhira, 1991, pp. 211-212.

82 al-Zāwī, Wulāt Ṭarābulis al-ghārb, pp. 508, 523.

83 al-Jamal, Shawqī 'Ațallāh, 'Abd al-llāh Ibrāhīm and Rabāb Salām, Tārīkh 'Aūrūbbā al-ḥadīth wa al-mu 'ạșir min mu'tamar Fìyinna ḥatā al'ān, vol. 2, Dār al-thaqāfā li-l-nashr wa al-tawzī', al-Qāhira, n.d., p. 38; see also Porter, Andrew, European Imperialism, 1860-1914, Macmillan, Houndmills, 1994.

84 al-Zāwì, Wulāt Ṭarābulis al-ghārb, p. 270. 
(Astana) to defend the city in case of any attack. ${ }^{85}$ These efforts were accompanied by the appointment of Ahmed Rasim Pasha as a governor of the province in 1881. This was a critical period because it coincided with France's declaration of Tunisia as a French protectorate and with British preparations to occupy Egypt. ${ }^{86}$ Ahmed Rasim Pasha lived up to the expectations entrusted to him by the Ottoman Empire in this regard, as his political stance was defiantly anticolonialist. Ahmed Rasim Pasha (1881-1898) attended first to the political stability of the province. He lifted the European protection from some Arab nationals and brought them back under the authority of the Ottoman Empire. During his rule the province was affected by a number of conflicts, particularly between tribes inhabiting the border region between Tripoli and Tunisia. Although Rasim Pasha succeeded in reducing the frequency of these disputes, he was not able to end them entirely. ${ }^{87} \mathrm{He}$ was then faced by a new problem, namely Italian ambitions over Tripoli, which led to some direct conflicts with the Italian consul, particularly after the Italian government began focusing its activities and economic interests in the province by encouraging immigration and other efforts to control Tripoli. ${ }^{88}$ As a result of these developments and the desire of Italy to control Tripoli, the local people began to feel the gravity of the situation and feared the advent of European colonization. This changed the whole situation in the province as it motivated the local people to support the governors; for instance, Mohammad Nazif Pasha's ruled in $1880 .^{89} \mathrm{He}$ succeeded in strengthening the fortifications of the center of Tripoli, specifically in the northwest of the city, such as the towers of al-Hamedia, al-Frarh, Sidi Mansour, and Gargarsh. He also set up canons on the left and the right side of the city. ${ }^{90}$ He was assisted by the local inhabitants in all of this. Their fear of European occupation led them to support him, despite their opposition in other instances, and even to offer financial assistance for the construction of material defences. Mohammad Nazif Pasha also focused on the central and eastern regions and established a new political administration under the control of Sirte. His successor, Ahmed Rasim Pasha, remained in office for a long period that lasted until 1898, when he was replaced by Namik Pasha. ${ }^{91}$ To highlight the economic situation in the pro-

85 al-Tilīsī, Hikāyat madīnat, p. 170.

86 See Ganiage, Jean, Les origines du protectorat français en Tunisie (1861-1881), Maison Tunisienne de l'Edition, 1961.

87 al-Zāwī, Wulāt Ṭarābulis al-ghārb, pp. 273-274.

88 al-Tilīsī, Hikāyat madīnat, p. 174.

89 Rūsi, Lỉbiyā mundhu al-fatḥ al arabì ḥatā sanat 1911, p. 384.

90 al-Zāwī, Wulāt Țarābulis al-ghārb, p. 274.

91 Ibid., p. 276. 
vince of Tripoli in the context of revolt and European imperialism between 1870 and 1884, the following tables offer detailed information on natural resources such as the different types of agricultural products and the quantity of produce with regard to most aspects of the economy in Tripoli. This is to understand how this economy was so important for local and external actors competing for control over the region. The figures have mainly been drawn from documents found in a report in the Political Archive (Politisches Archiv) in Berlin, Germany.

Table 1: The number of fruit trees in the province of Tripoli in 1869

\begin{tabular}{ll}
\hline Fruit & Number of trees \\
\hline Olive & 3.447 .040 \\
Palm & 2.687 .740 \\
Orange & 450.000 \\
Lemon & 220.000 \\
Pomegranate & 12.580 \\
Apricot & 11.300 \\
Apple & 1.400 \\
Other & 15.245 \\
\hline
\end{tabular}

The information in this table ${ }^{92}$ dates to the period between July 1869 and October 1888 , and included the number of trees in the province of Tripoli. The table shows that the number of olive and palm trees was higher than that of other trees, a point which reveals their significance to the economy of the province. Given the large numbers of olive trees in Tripoli, olive oil was also produced in large quantities, as stated in the report.

In the same report, the quantities of crops and cereal in the same period are presented in table 2 below. ${ }^{93}$

92 Politisches Archiv des Auswärtigen Amts, Allgemeine Angelegenheiten von Tripolis, Das Kaiserliche Konsulat in Tripoli, Bd. 1, vom Juli 1869 bis Oktober 1888, R901/52506.

93 Ibid. 
Table 2: Quantities of crops and cereal produced in 1869

\begin{tabular}{ll}
\hline Crop & Quantity in Kilogram \\
\hline Barley & 50.000 .000 \\
Wheat & 22.500 .000 \\
Sorghum & 300.000 \\
White Sorghum & 15.000 \\
\hline
\end{tabular}

The following table $\mathrm{e}^{94}$ presents the production of fruits and vegetables in the province of Tripoli in the same period (1870-1884).

Table 3: Production of fruits and vegetables (1870-1884)

\begin{tabular}{ll}
\hline Quality & Quantity in Kilogram \\
\hline Orange and Lemon & 40.000 .000 \\
Date & 28.500 .000 \\
Pumpkin and Watermelon & 1.000 .000 \\
Dried Fig & 672.000 \\
Ḥinnah & 275.000 \\
Onion & 240.000 \\
Yam & 135.000 \\
Truffle & 105.000 \\
Carob & 60.000 \\
Pomegranate & 28.200 \\
Raisin & 27.000 \\
Apple & 13.800 \\
Pear & 10.500 \\
Quince & 5.000 \\
Tobacco flower & 3.300 \\
Rubber & 1.200 \\
\hline
\end{tabular}

It was not only statistics on agricultural products that were presented in the report, the species and numbers of animals and livestock in the province of Tripoli were as well, and are illustrated in table 4 below. ${ }^{95}$

94 Ibid.

95 Ibid. 
Table 4: Species and numbers of animals and livestock in Tripoli

\begin{tabular}{ll}
\hline Species & Number \\
\hline Lamb & 700.0000 \\
Camel & 150.0000 \\
Young sheep & 120.0000 \\
Ram & 587.000 \\
Capricorn & 400.000 \\
Goat & 350.000 \\
Bird (chicken and rooster) & 110.000 \\
Ox & 110.000 \\
Cow & 38.000 \\
Mule & 15.000 \\
Pony & 14.000 \\
Horse & 12.000 \\
\hline
\end{tabular}

As land constituted a significant issue in the economic life of Tripoli, the same report indicated the different types of soil and their uses, including agricultural land and gardens, the land used by pastures for animals, uncultivated land in the desert, and residential areas. ${ }^{96}$ The main industries in Tripoli were metal and leather industries, textiles, and straw mats. The metal and leather industries had received the special encouragement of Samih Pasha ${ }^{97}$ who ruled the province in 1874 and $1875 .{ }^{98}$ These industries were represented in certain markets in various parts of the province. Each craft had its special market. The markets were not limited to the industries of silk, gold, silver, jewelry, and copper, which were known as Sūq al-qāṣdarha. There was also some manufacturing of iron and other metals. The inhabitants of Tripoli were interested in the textile industry. It represented one of the most important and largest industries in the province. Wool was produced by men and women equally. Production varied between silk gowns, robes made of wool, and carpets mainly produced in Misurata. ${ }^{99}$ These products were sold in the local markets and locally consumed as traditional dresses. Some-

96 Ibid.

97 al-Zāwī, Wulāt Ṭarābulis al-ghārb, p. 264.

98 Ibrāhīm, 'Abd al-llāh 'Alī, "Anmāṭ al-tijārā al-dakhīliyya fī wilāyāt Ṭarābulis al-ghārb wa Barqa fī al-niṣf al-thānī min al-qarn al-tāsi' 'ashr”, Majallat al-buḥūth al-tārīkhiyya, 6-2, markaz jihād al-lībìyyīn ḍid al-ghazū al-iṭāî, jāmi'at al-Fātiḥ, Ṭarābulis, 1984, p. 402.

99 Ibn Mūsā, al-Mujtama 'al- 'arabì al-lībì, p. 65; Kūrū, Lìbiyā athnā'’ al-'ahd al-'ūthmānī al-thānī, p. 148. 
times, they were exported to Tunis. Straw mats called hașīr (or kalìm) were concentrated in two main areas: Taworgha and Tajura. ${ }^{100}$ They were produced and used locally in huge quantities. Like the other Ottoman provinces, the Arabic provinces ruled by the Ottoman Empire were organized under a very complex system of taxation. The Ottoman taxation system in Tripoli included taxes called werko, ${ }^{101}$ the oppressive property tax implemented by an 1858 Ottoman law. Other taxes included the tithe, taxes on inheritances and on commercial transactions, in addition to the real estate tax and taxes on precious metals. The werko was a tribute annual tax known as mīri, which was imposed on the population of Tripoli. It was considered one of the most important taxes in the province. It was taken from every adult male and was used by the Ottomans to cover administrative expenses. ${ }^{102}$ In addition, there were taxes on livestock that varied depending on type. For a camel, for example, the owner should pay 35 Ottoman Qirsh, ${ }^{103}$ whilst the sum for each cow was 17.5 Ottoman Qirsh. Taxes were also imposed on trees and wells. ${ }^{104}$ A new tax was introduced in 1897 to pay for the exemption from military service. The tax was known as al-Jihädiyya and the main goal behind was to cover the expenses of the Greek-Turkish war. It is noteworthy that the government in Istanbul imposed this tax for only one year, but the governors in Tripoli made it permanent, and included it within the werko tax. ${ }^{105}$ The tithe was paid on agricultural products. Farmers had to pay one tenth of their agriculture production such as wheat, barley and olives to the government. Because this tax was linked mainly with the quantity and quality of production it differed from one year to another. ${ }^{106}$ In addition, other taxes and revenues included the property tax, stamps tax, and taxes paid in ports, which were imposed in $1886 .{ }^{107}$ It should be noted that the families of the aristocracy were exempted from these

100 Kūrū, Lìbiyā athnā' al- 'ahd al- 'ūthmānī al-thānī, pp. 65-67.

101 Brūshīn, Tārīkh Lìbiyā min nihāyāt al-qarn al-tāsi' 'ashar, pp. 64-65.

102 Ibid.

103 There is different currencies mentioned in this book as it was mentioned in the literature, I could not find any document that helps me to unify the different currencies.

104 Kūrū, Lìbiyā athnā' al-' 'ahd al- 'ūthmānī al-thānī, pp. 37, 38, 46.

105 Kākiyā, Antūnī, Lìbiyā fì al- 'ahd al- 'ùthmānī al-thānī 1835-1911, translated by Yūsuf Afandī al-'Asalī, Ṭarābulis, 1946, p. 91, an Arabic translation of Cachia, A.J., Libya under the Second Ottoman Occupation (1835-1911), Tripoli, 1945.

106 al-Wībā, Kāmil 'Alī, al-Idārā al- 'ūthmānīyyā fī Ṭarābulis al-ghārb, revised by Ṭāhir Khalf alBaka', markaz jihād al-lībīyyīn li-l-dirāsāt al-tārīkhiyya, Ṭarābulis, 2005, p. 135.

107 al-Sūrī, Șālāh al-Dīn Ḥasan, "al-ḍarā'ib al-'ūthmānīyyā fī wilāyāt Ṭarābulis al-ghārb wa Mutașarrīfīyya Binghāzī fī al-'ahd al- 'ūthmānī al-thānī mashākil al-ḍaghṭ wa al-tawattur”, $M a$ jallat al-buhūth al-tārīkhiyya, 6-2, markaz jihād al-lībīyyīn ḍid al-ghazū al-ițāî̀, jāmi' at al-Fātiḥ, Ṭarābulis, 1984, p. 394. 
taxes. ${ }^{108}$ Exempted groups included the al-Kuwārighliyya,${ }^{109}$ the Ashrāf, and the shyūkh (singular: shaykh). Despite these exemptions they could still be harassed to pay taxes. For example, the sons of Shaykh 'Abd al-Sālām al- 'Asmār in Zlitan were harassed for years by the tax collectors and the judiciary, who asked them to provide supplies, including food, for free. For this reason, they wrote to the Ottoman sultan in Istanbul to inform him of these harassments. They asked the sultan to provide them with protection and to send an order to inform the local authorities that they were exempted from paying taxes. The sultan then reacted positively and strengthened their situation. ${ }^{110}$ All the non-Muslims and particularly the Jews who lived in the province of Tripoli were exempted from military service. For this exemption, they had to pay 30 penny/piaster. ${ }^{111}$ Customs were also paid in ports. These were equivalent to $1 \%$ on exported goods and $8 \%$ on imported goods, in addition to the taxes required at ports. In the case of taxes paid at ports, the Ottomans only imposed taxes on Arab ships; ships of other countries were exempted. Furthermore, there were also taxes on post and telegraph. The revenues from the taxes were sent to Istanbul. ${ }^{112}$

108 al-Wībā, al-Idāra al- 'ūthmānīyyā fĩ Ṭarābulis al-ghārb, p. 150; Ibn Mūsā, al-Mujtama' al'arabì al-lībì, p. 232.

109 This is a Turkish name given to a group of people in the province of Tripoli. It is said that they were born to the Turkish soldiers who were married to women from the local population. The families tended to concentrate in the cities of Tripoli, al-Zawiya, Misurata and Zeltin and other cities in the coast, see also Kamālī, Ismā̄îl, Sukkān Ṭarābulis al-ghārb, translated by Ḥasan al-Hādī bin Yūnis, markaz jihād al-lībīyyīn li-l-dirāsāt al-tārīkhiyya, Ṭarābulis, 1997, p. 60.

110 Wathīqā 40/30, al-markaz al-wațanī li-l-māḥafūọāt, Ṭarābulis.

111 Kūrū, Lìbiyā athnā' al- 'ahd al-'ūthmānī al-thānī, p. 39; Ibn Mūsā, al-Mujtama' al- 'arabì allībì, p. 246.

112 Ibn Mūsā, al-Mujtama' al-'arabì al-lībī, p. 246. 


\subsection{Cities as Centers of Trade Networks}

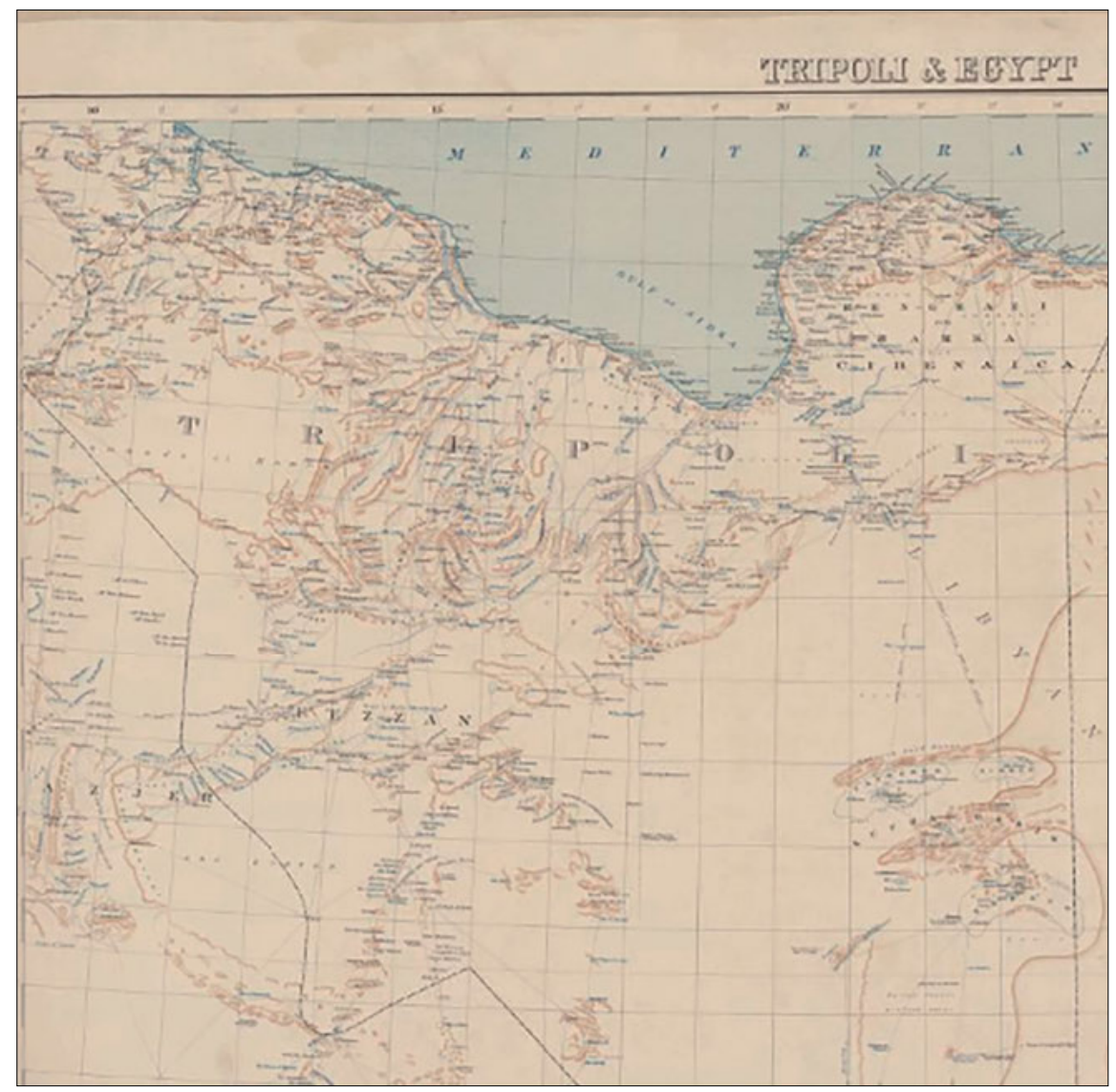

Map 1: Cities of the province of Tripoli

\section{Tripoli and Benghazi}

The natural consequence of the development of trade at various levels was the success and reputation the cities of Tripoli and Benghazi gained in North Africa. They became the most important commercial centers of the coastal region and formed a link between north and south, and east and west. The city of Tripoli was considered the departure and arrival point for commercial convoys between north 
and south of the Sahara. ${ }^{113}$ The port played a very important role in the revitalization of commercial maritime traffic. This increased markedly at the end of the $19^{\text {th }}$ century, both in terms of the value of exports and imports, and in the steady increase in the number of ships that frequently passed by Tripoli. There was a particularly marked increase in the number of Italian private vessels as a result of the increasing interest of the Italian government, which resulted in intensifying their economic activities in Tripoli and in turn boosted maritime commercial traffic. ${ }^{114}$ This maritime activity reached a highpoint in the period $1872-1881 .{ }^{115}$ The reason behind the development and recovery of the caravan trade was the progressing political situation in Tripoli and the keenness and commitment of some governors to develop this trade. The elimination of the rebels who worked against the Ottoman authority was the first task that increased the sense of security and ensured the safety of the trade caravans. Moreover, the authorities reinforced their influence in the interior areas, especially in the province (liw $\vec{a})$ of Fezzan and in the city of Ghadames, which were considered the main centers along the caravan trade route with the kingdoms of Sudan. ${ }^{116}$ In addition, the Ottoman authorities rebuilt their relations with the kingdoms of Sudan, especially the kingdom of Kanem and Borno in the south in the second half of the $19^{\text {th }}$ century. These relations had deteriorated during the rule of the al-Käramanlì dynasty. Furthermore, the Ottomans tried to restore their relations with the Kingdom of Wadai (in Chad) and maintain this region within their empire. ${ }^{117}$ The Ottoman authorities had also taken other measures, including allowing the British government to open

113 For more information see the work of Martel, André, Les confins Saharo-Tripolitains de la Tunisie, 1881-1911, Presses Universitaires de France, Paris, 1965 and Lafi, Nora, “Tripoli de Barbarie, port de mer, port du désert (1795-1835)”, in Méditerranée, mer ouverte: actes du colloque de Marseille (21-23 Septembre 1995)/Tome 2, XIXe et XXe siècles, ed. by Christiane Villain-Gandossi, Louis Durteste and Salvino Bussutil, International Foundation, Malta, 1997, pp. 657-666.

114 Hūwīdi, Mușțafa'Alī, "al-Zurūf al-iqtișādīyyā, fĩ wilāyāt Țarābulis al-ghārb qubail al-ghazū al-ițālī”, al-dawr al-iqtiṣādī li-madīnat Ṭarābulis ka-ḥalaqat wasl baina 'Aūrūbbā wa Afrīqiyā (18351950), ed. by Khalīfa Moḥammad al-Duwaybi, a'māl al-nadwā al-'ilmiyya al-thālitha allatī 'uqidat bi-l-markaz fỉ 3/10/1998, markaz jihād al-lībīyyīn li-l-dirāsāt al-tārīkhiyya, Ṭarābulis, 2008, p. 204. 115 Anderson, Lisa, The State and Social Transformation in Tunisia and Libya, Princeton University Press, Princeton, 1987.

116 Lafi, Nora, Ghadamès, cité oasis entre empire Ottoman et colonialisme, in Libya tra Mediterraneo e mondo islamico, ed. by Federico Cresti, A. Giuffrè, Milano, 2006, pp. 55-70.

117 Concerning the Ottoman Empire and Sahara, see Minawi, Mostafa, "A New Start? Libyan History and Historiography at a Time of Historical Transition" a post-workshop report on the international workshop "Libyan History and Historiography at a Time of Historical Transition", held at Zentrum Moderner Orient in Berlin (2012), report consulted on September 3, 2020, https://www. eume-berlin.de/fileadmin/eume/pdf/arbeitsgespraeche/Minawi-Libyan_History-Report.pdf. 
two branches of their consulate in Tripoli in Murzuq and Ghadames and permitting the French to open a branch of their consulate. All of these efforts contributed to stimulating the caravan trade with the Sudanese kingdoms and this finally had a significant positive impact. The number of caravans from the province of Tripoli increased. ${ }^{118}$ At the time, Benghazi was as important as Tripoli with the number of trades conveys which were passing through. The port of Benghazi received goods from Wadai, and Timbuktu (in Mali). To give just one example, in the second half of the $19^{\text {th }}$ century, large quantities of ostrich feathers were imported from Wadai by caravan to Benghazi, where they were exchanged for cotton textiles from Europe. The historical literature indicates that the number of convoys from Benghazi to sub-Saharan Africa was relatively large in 1893, employing a total of 1.111 camels to transport the goods. The number of camels carrying the goods also increased to 1.232 and reached 2.238 by $1899 .^{119}$ This clearly demonstrates active trade between the north and the south. It also demonstrates how the authorities of Sudan's sub-Saharan kingdoms were keen to continue this trade that enriched the local markets, while at the same time representing a connection with the north. The sultans of the Sudanese kingdoms were collecting the tithe (or öşür, meaning “tenth” in English) imposed on goods transported to and from Tripoli, as well as different amounts of money to facilitate the slave trade that was conducted across the land. ${ }^{120}$ This played an important role in enriching the market in these kingdoms. ${ }^{121}$

\section{Sawkanh}

This city is located in the southeast of the province of Tripoli and was considered a center of trade toward the interior cities and regions of south-central Africa. The

118 See for example: the thesis of al-Ḥindīīi, Sa īd, Université de Provence, Aix, Marseille, 1992, and other publications such as al-Ḥindīiñ, "Tațawwur tijārat al-qawāfil fī Wilāyāt Ṭarābulis alghārb”, p. 696.

119 al-Ma'lūl, Sālim Moḥammad, "Daūr Awjilah fī tawthīq al-'ālāqāt ma' mamālik bilād alSūdān mindhu al-qarn al-'āshir ḥatā mațla' al-qarn al-'aishrīn”, Awjilah baina al-māḍi wa alḥạḍir (1950-1951), a'māl al-nadwā al-'ilmiyya al-sābi'ā allatī 'uqidat bī- madīnat Awjilah (1720/9/2009), ed. by Moḥammad Bashīr Suwīsī, markaz jihād al-lībīyyīn li-l-dirāsāt al-tārīkhīyyā, Ṭarābulis, 2009, pp. 103-104.

120 Kūrū, Lìbiyā athnā' al- 'ahd al-' 'ùthmānī al-thānī, p. 121.

121 See the work of Panzac, Daniel, Les corsaires barbaresques. La fin d'une épopée, 1800-1820, CNRS Editions, Paris, 1999 and the English translation, Corsairs, Barbary, The End of a Legend 1800-1820, Brill, London, Boston, 2005, p. 353. 
city gained its significance from its strategic geographical location on the route that runs between Tripoli and Borno in (Nigeria) and on the pilgrimage route between east and west. ${ }^{122}$ It is on a plane extending toward the east. Sawkanh was also considered the south gate to the oases in the Jofra region in the province (liwa $\bar{a}$ ) of Fezzan. Its climate is famous for hot summers and cold winters. It was mentioned by the German traveller Gustav Nachtigal, ${ }^{123}$ who estimated the population to be about 3.000 in $1869 .{ }^{124}$ The city had been active in transit trade. The merchants of the city were able to amass considerable wealth, seen as business agents ( $\left.w u k a l \bar{a}^{\prime}\right)$ in the north and south because they had established linkages with the sultans of Borno, the Hijaz, and the city of Istanbul. Sawkanh was also a resting station for trade convoys headed toward both north and south. The city provided the trade convoys with food such as dates, meat, bread and so forth. Another factor that boosted the importance of the city was that the local people rented their camels for trade and some inhabitants volunteered to serve as escorts to the convoys. ${ }^{125}$

\section{Ghadames}

Ghadames had a special significance. First, it is an ancient city with a privileged geographic location. It is located to the northwest of the city of Tripoli in a mountainous area known as al-Hamada al-Hamra' $(640 \mathrm{~km}$ from the center of the province of Tripoli), on the borders with Tunisia and Algeria. These borders were important because Algeria was under French occupation in 1880, at the same time as the French were trying to extend their influence to Tunisia. Ghadames was an important trade center between Algeria and Tunis. France then tried to take control of parts of Ghadames and to change the trade routes to pass through Tunisia. The city center is also only $9 \mathrm{~km}$ from the Algerian border, whilst the

122 al-'Afīf, Mukhtār 'Ūthmān, "Namādhij min al-ṣilāt al-tijāriyya bain Sawkanh wa Ṭarābulis khilāl al-'ahd al-'ūthmānī al-thānī 1835-1911”, Majallat al-buhūth al-tārīkhiyya, 21-2, markaz jihād al-lībīyyīn li-l-dirāsāt al-tārīkhiyya, Țarābulis, 1999, pp. 123, 125.

123 See Nachtigal, Gustav, Sahara und Sudan; on his biography see also Priesner, Claus, "Nachtigal, Gustav" in Neue Deutsche Biographie, vol. 18, Duncker \& Humblot, Berlin, 1997, pp. 682-684.

124 Nachtigal, Sahara und Sudan, p. 148; Ghānim, 'Imād al-Dīn, "al-Mujtama' al-lībī ladā alraḥḥ̄àla al-'aūrūbbīyyīn”, al-Mujtam 'al-lībī 1835-1950, a'māl al-nadwā al-'ilmiyya al-thāmina allatī 'uqidat bi-l-markaz fī al-fatra min 26-27/9/2000, ed. by Moḥammad al-Ṭāhir al-Jarārī, markaz jihād al-lībīyyīn li-l-dirāsāt al-tārīkhiyya, Ṭarābulis, 2005, p. 330; see also Panzac, Daniel, La population de l'Empire Ottoman, Cinquante ans (1941-1990) de publications et de recherches, CNRS-IREMAM, Aix-en-Provence, 1993.

125 al-'Afïf, "Namādhij min al-ṣilāt al-tijāriyya bain Sawkanh wa Ṭarābulis”, p. 125. 
city of Ghat is about $800 \mathrm{~km}$ away. ${ }^{126}$ Another feature that increased Ghadames' importance is the existence of many water sources or springs called 'auyūn (singular: 'ayn); the most famous being 'Ayn al-Faras. ${ }^{127}$ Most of the residents of the area drew water for their animals and irrigated their farms from 'Ayn al-Faras. ${ }^{128}$ The city was of great importance for the trade convoys. It represented the main place where they exchanged their tired camels for rested animals to continue their journey to Ghat, where the camels were replaced again. This was the established pattern of all convoys from Tripoli to Kanem in $1897 .{ }^{129}$ Economically, the city was a center of trade and a meeting place for convoys (see Picture 1), which contributed to its status an important commercial city. It was also a large oasis in the desert in its own right, rich in palm trees, gardens, and wells.

Ghadames' traders assumed a privileged position both within the province and beyond. They had permanent trade agents in different places, like Tunis, ${ }^{130} \mathrm{Tim}$ buktu and many other cities of the region of Sudan, Sokoto (in Nigeria), Kanem and Wadai. It is noted that these agents were from the same city and often the sons of the merchants themselves. ${ }^{131}$ Ghadames also represented an important point of cultural interchange between the Islamic culture and society that dominated in the north and the less Islamically oriented culture of the sub-Saharan regions. ${ }^{132}$ The trade that was taking place between north and south of the Sahara reveals how the two parts of Africa were complementing each other economically. ${ }^{133}$

126 al-Ma 'ūl, Fātima Moḥammad, madīnat Ghadāmis dirāsa fi jughrāfiyat al-mudun, al-Qāhira, 2006, p. 12.

127 al-'Ahwwal, Khalīfa Moḥammad, “al-Jāliyāt al-ajnabīyya fī Lībiyā (1835-1950)”, al-Mujtama c al-lībī (1835-1950), a'māl al-nadwā al-'ilmiyya al-thāmina allatī 'uqidat bi-l-markaz fī al-fatra min 26-27/9/2000, ed. by Moḥammad al-Ṭāhir al-Jarārī, markaz jihād al-lībīyyīn li-l-dirāsāt altārīkhiyya, Țarābulis, 2005, p. 456.

128 Abū Shārib, “Tijārat al-qawāfil”, p. 135.

129 Nājī, Tārīkh Ṭarābulis al-ghārb, p. 63.

130 Yūsha', Bashīr Qāsim, Wathīqā 142, 1884, Wathā’iq Ghadāmis wathā’iq tijāriyya tārīkhiyya ijtimā’iyya 949H/1542M-1343H/1924M, markaz jihād al-lībīyyīn li-l-dirāsāt al-tārīkhiyya, Țarābulis, 1995.

131 Martel, Les Confins Saharao Tripoltains de la Tunisie (1881-1911), p. 93; see also al-Ṭawīl, Imhịmmad Sa'īd, "al-Șirā' al-duwalī 'alā madīnat Ghadāmis khilāl al-niṣf al-thānī min al-qarn al-tāsi'a 'ashar wa in'ikāsātuh 'alā tijāratihā”, a māal al-nadwā al-'ilamiyya al-tārīkhiyya ḥawla tārīkh Ghadāmis min khilāl kitābāt al-raḥḥāla wa al-mū'arrrikhīn, introduced by Nūr al-Dīn alThinī, markaz jihād al-lībīyyīn li-l-dirāsāt al-tārīkhiyya, Ṭarābulis, 2003, p. 199.

132 See Marmol y Carvajal, Louis, L'Afrique de Marmol, ed. by Richelet Pierre, 3 vols., Paris, 1667, p. 58.

133 al-Sāqizlī, 'Abd al-Lațîf Sulaymān, Lỉbiyā al-thawrā, vol. 1, Dār mimfīs li-l-tịbā'a wa alnashr, al-Qāhira, 1398H; Sālim al-Ma lūl, "Daūr Awjilah fī tawthīq al-'ālāqāt ma' mamālik bilād al-Sūdān”, p. 93. 


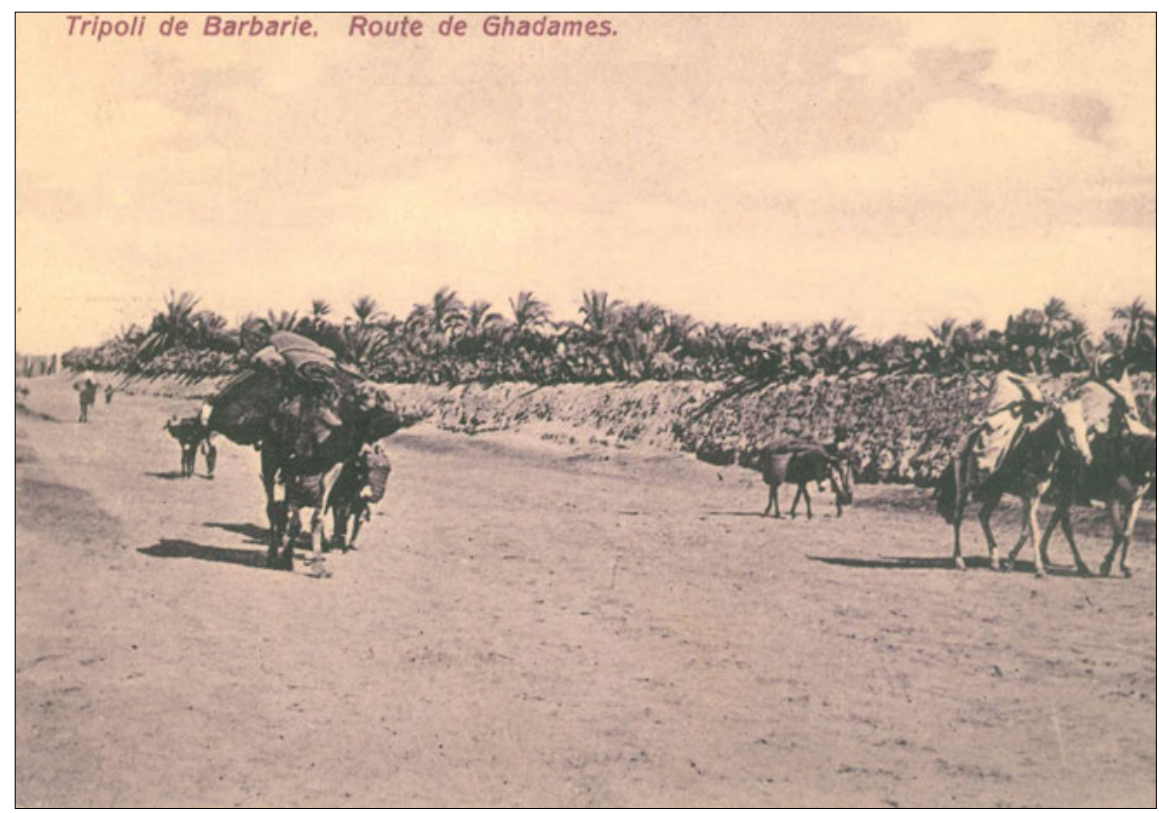

Picture 1: Example of a convoy in Ghadames in 1884

\section{Network of Caravan Trade Routes}

The other factor contributing to the economic importance of the province of Tripoli was the network of routes used by convoys to travel back and forth. These routes had two characteristics (see Map 4). Firstly, they had been in use for a long time and were therefore well known to all who were involved in trade in Africa. Secondly, they constituted a network that extended outward to connect different parts of Africa to the rest of the Ottoman provinces. There were several important routes.

The route of Tripoli to Kano passed through a series of small towns and villages and some tribal groupings until it reached south to Chad, and went through the southwest passing areas like al-Aairr and Zander to Kano. ${ }^{134}$ This route passed through Ghadames. 
The Tripoli-Borno (Nigeria) ${ }^{135}$ route ended at Coca on the shores of Lake Chad. It was the most direct route toward the Central of Africa. The duration of a round-trip was six months. ${ }^{136}$

The Tripoli-Benghazi route was used by convoys from Tripoli traveling to Benghazi and became a rallying point for many convoys. In Benghazi there were representatives responsible for monitoring the convoys, which belonged to Tripoli until they left. On the way to Tripoli they passed through such places as Wadai, al-Kufra, Tebsti, Anwaja and Enski.

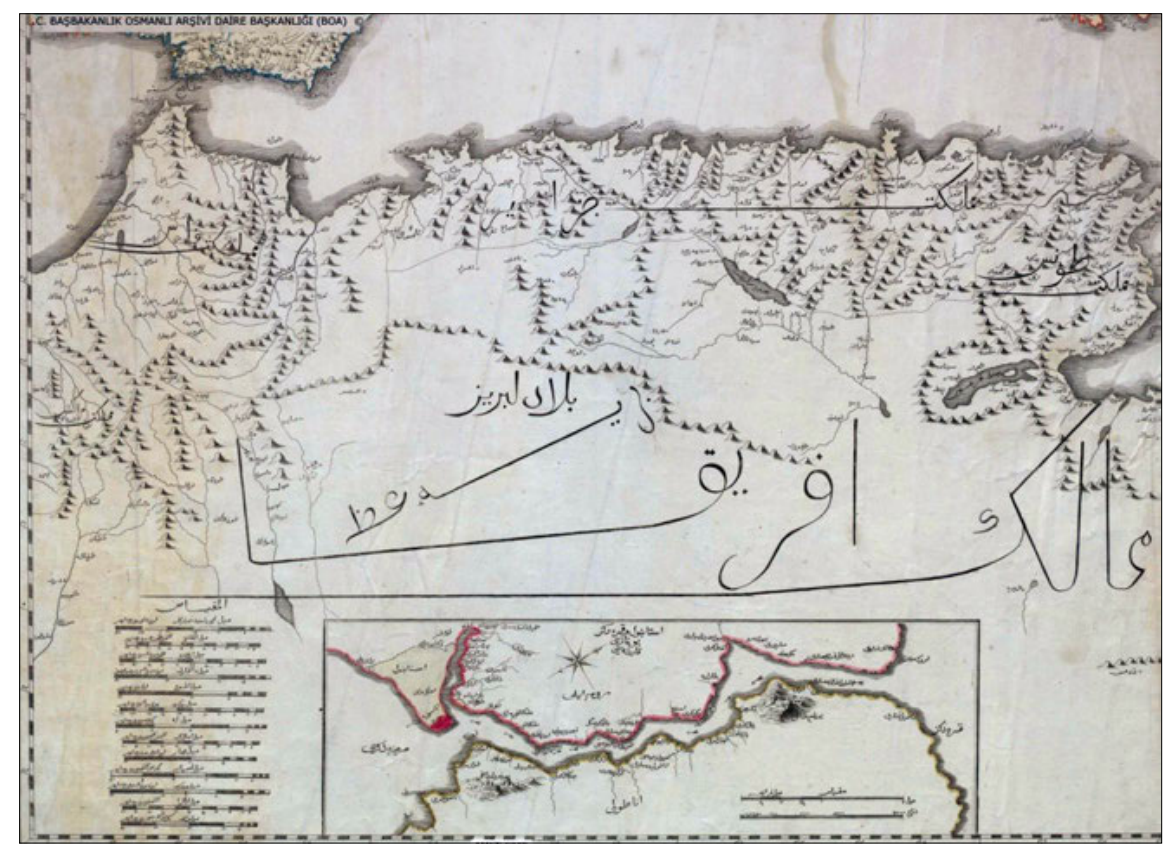

Map 2: Ottoman African provinces

The middle route to Sudan was a longer but safer, starting from the city of Tripoli, passing through Ghadames and reaching Kano. It is notable that most of the users and the supervisors of this route were traders from Ghadames. The advantage of this route was that it generated large profits for the province. ${ }^{137}$ In addition, the

135 'Āmir, Maḥmūd 'Alī, Tārīkh al-maghrib al-'arabī al-ḥadìth, Lìbiyā, Jāmi'at Dimashq, Dimashq, 1987, p. 157.

136 Kūrū, Lìbiyā athnā' al- 'ahd al- 'ūthmānì al-thānī, pp. 86-87.

137 Ibid., p. 84-85. 
traders from Ghadames were known for their intelligence and were very active. This was because they had grown up in trading families and were always surrounded by traders coming to their city, besides their good knowledge of several African languages and dialects in addition to Arabic. This helped them in turn to extend their trade outside their city, with some of them were very famous in Kano, Nubi and Zander in Africa and some cities in Tunis. The estimated total number of merchants from Ghadames during the second half of the $19^{\text {th }}$ century was estimated to be $129 .{ }^{138}$

The desert route linked Tripoli with the oases through Sawkanh, Zawilah, Awjilah, al-Jaghbub to Siwa, and Kradash in the west of Cairo. This route also linked Tripoli to the Tunisian and Algerian commercial centers. ${ }^{139}$ There was more trade with Tunisia than with the other two provinces. These exchanges were supervised by the Tunisian agents in Tripoli, and the same in Tunisia. The exchange of goods included both domestic goods and those coming from Europe and Africa. ${ }^{140}$ Trade with Algeria was limited to Tar (al-tronh) and Hina (hinnah) also known as Lawsonia inermis.

The coastal route: This route was divided into two main legs, one heading toward the east, starting from Tripoli and passing through the major coastal cities and continuing through the border with Egypt until reaching both Alexandria and Cairo. Trade with Egypt included trade in rice and sugar and imported livestock, hinnah, mats, and other manufactured goods. These were transported by convoys or ships of the Italian and Maltese companies. ${ }^{141}$ The second route headed west toward the Tunisian cities such as Sfax, Kairouan and Tunis, which were involved in trade and economic exchange. The main difference between these routes in trading terms is that the transport of goods was more expensive on the coastal route trade the land routes.

138 al-Ṭawīl, "al-Ṣirā' al-duwalī 'alā madīnat Ghadāmis”, p. 64.

139 Ibn Mūsā, al-Mujtama' al- 'arabī al-lìbī, p. 64.

140 Alghafal, al- 'Ālāqāt al-lībiyyā al-tūnīsìyya, p. 144.

141 Kūrū, Lìbiyā athnā' al-'ahd al- 'ūthmānì al-thānī, p. 77-78 


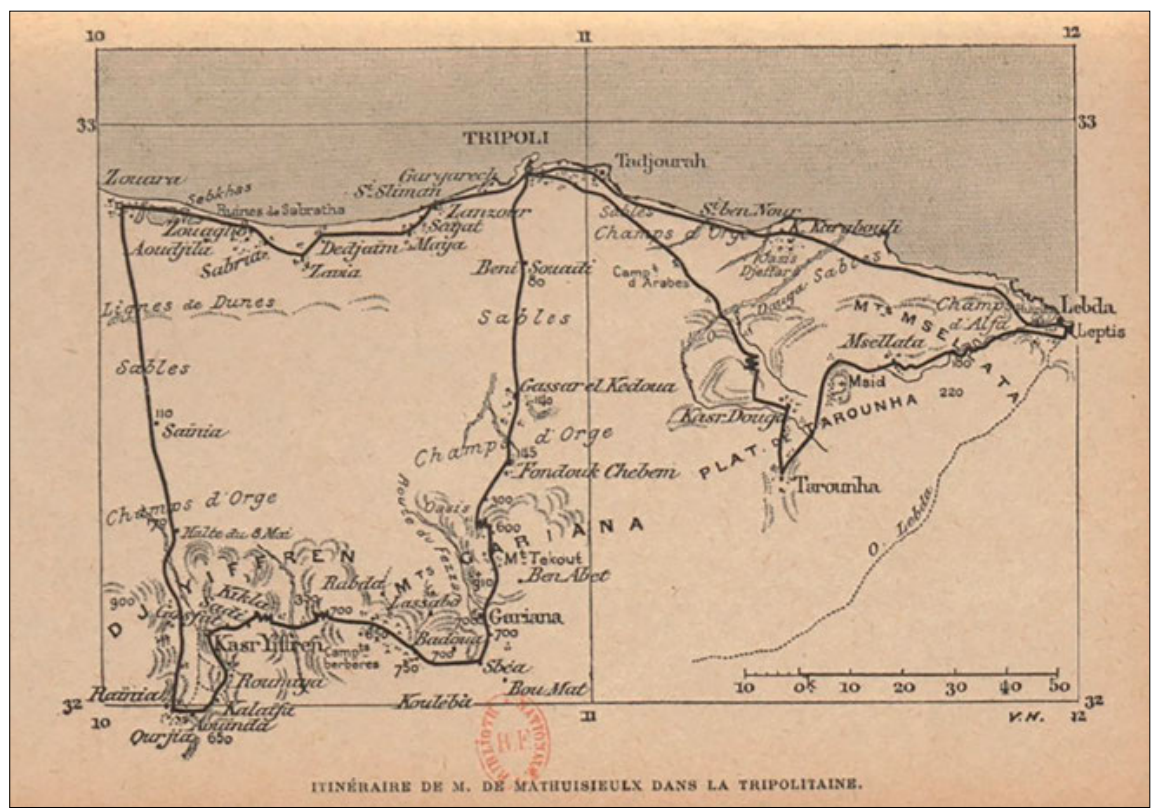

Map 3: Caravan trade routes in the province of Tripoli in the $19^{\text {th }}$ century

These routes facilitated trade between the regions and were used to transport different goods such as grains (barley, wheat, corn), gold and silver jewelry, glass, dates, spices, horse saddles, livestock and carpets, ${ }^{142}$ in addition to goods coming from Europe, including silk imported from Lyon in France, cotton fabrics from Britain, and handicraft tissues that were made in India, perfumes of various kinds, weapons and other goods. ${ }^{143}$ These routes also helped transport African products and goods such as ostriches, gold, ivory and slaves. Some convoys also carried goat skins and leather goods. ${ }^{144}$ To sum up, the preceding overview has presented the geographic, strategic and economic importance of Tripoli and has indicated why the province was so important to control. The situation in the province of Tripoli played a major role in shaping the relationship between Tripoli and the other Ottoman provinces as well as with the European powers.

142 'Āmir, Tārīkh al-maghrib al'arabì, p. 158.

143 al-Ḥindīrī, "Tațawwur tijārat al-qawāfil fī wilāyāt Ṭarābulis”, p. 703.

144 Kūrū, Lìbiyā athnā' al- 'ahd al- 'ūthmānī al-thānī, pp. 88-89; al-Ḥindīrī, "Tațawwur tijārat al-qawāfil fī wilāyāt Ṭarābulis”, p. 703. 


\section{Internal and Foreign Trade}

Trade in the province of Tripoli was directly supervised by the Ottoman governors and main families of the region. Some of the Ottoman governors of Tripoli were known for their work in developing the economic sector in general and trade, in particular. They focused their efforts on developing the trade sector that they viewed as important for developing the province's economy. Examples of such governors were Ali Rida Pasha ${ }^{145}$ (first term 1867-1870, second term 1872-1873), Mușțafa Asim (acting as governor 1870, second term 1874-1875), and Aḥmed Rasim Pasha (1881-1896). However, trade was sometimes disturbed when conflicts arose or groups rebelled against the ruling political authority. This includes the slave trade, which was taking place at that time both internally and externally. The region enjoyed great economic importance during the dynasty of al-Kâramanlī (1711-1835). Tripoli's economic importance at that time was mainly due to the large activity of trade convoys, which enjoyed the support of the ruling power, which in turn provided full protection to convoys coming to or departing the state. At the end of the rule of the al-Käramanlī dynasty, trade declined due to the political situation. During this time, the province was politically unstable and witnessed a series of revolts by the local population. Internal conflicts broke out among al-Kāramanlī dynasty members about who was eligible to rule. The family was divided into two groups: a group led by Mohammad Pasha, and the other led by Ali Pasha, the legitimate heir of the family. ${ }^{146}$ The Ottoman Empire resolved this conflict by sending a naval fleet to Tripoli. It consisted of 32 ships and was led by Najib Pasha who announced that he was coming to calm the situation and restore security in the province. Within a few days of his arrival, he managed to restore direct Ottoman rule and ended the rule of the al-Kāramanlī dynasty, ${ }^{147}$ and everything reverted to its previous state, including trade. ${ }^{148}$ Najib Pasha was then appointed as governer in 1835. Another period of decrease in trade was that after 1881. This time, the deterioration of trade was due to the decrease in demand for some material goods brought from Africa. For instance, Britain had been able to raise ostriches to produce feathers, which lowered the demand for feathers imported from Africa and directly contributed to the marked decline in prices. ${ }^{149}$

145 Concerning the implementation of the reforms with this governor see the study of Lafi, Nora, Une ville du Maghreb entre ancien régime et réformes ottomanes, op.cit.

146 Rūsi, Lìbiyā mundhu al-fath al 'arabī, p. 570.

147 Ziyāda, Niqūlā, Lỉbiyā fì al-'uṣūr al-ḥadìthā, ma'had al-buhūth wa al-dirāsāt al-'arabiyya, Jami'at al-duwal al-'arabiyya, al-Qāhira, 1966, p. 52.

148 Nājī, Tārīkh Țarābulis al-ghārb, p. 189.

149 Kūrū, Lìbiyā athnā' al- 'ahd al- 'ūthmānī al-thānī, p. 84; Nājī, Tārīkh Ṭarābulis al-ghārb, p. 68. 
This mode of trade focused on local products as well as imported products at other times. The province's wealth of livestock and agricultural production were the main source of livelihood for the locals; the transactions took place in markets held daily or weekly. There were permanent markets in the city of Tripoli, such as the al-Rubaa old market established by Osman Pasha al-Saqzle, who ruled between 1649 and 1672. It was distinctive in that it was completely covered by a ceiling. ${ }^{150}$ There were also weekly markets in most regions, such as the Friday market ${ }^{151}$ (see Picture 2), ${ }^{152}$ and the Sunday market for selling the sparto and halfa plants (Cortaderia selloana). ${ }^{153}$ These markets also existed in other coastal cities such as Zuwarah, Misurata and Benghazi, as well as southern cities including Murzuq, Ghadames and Ghat.

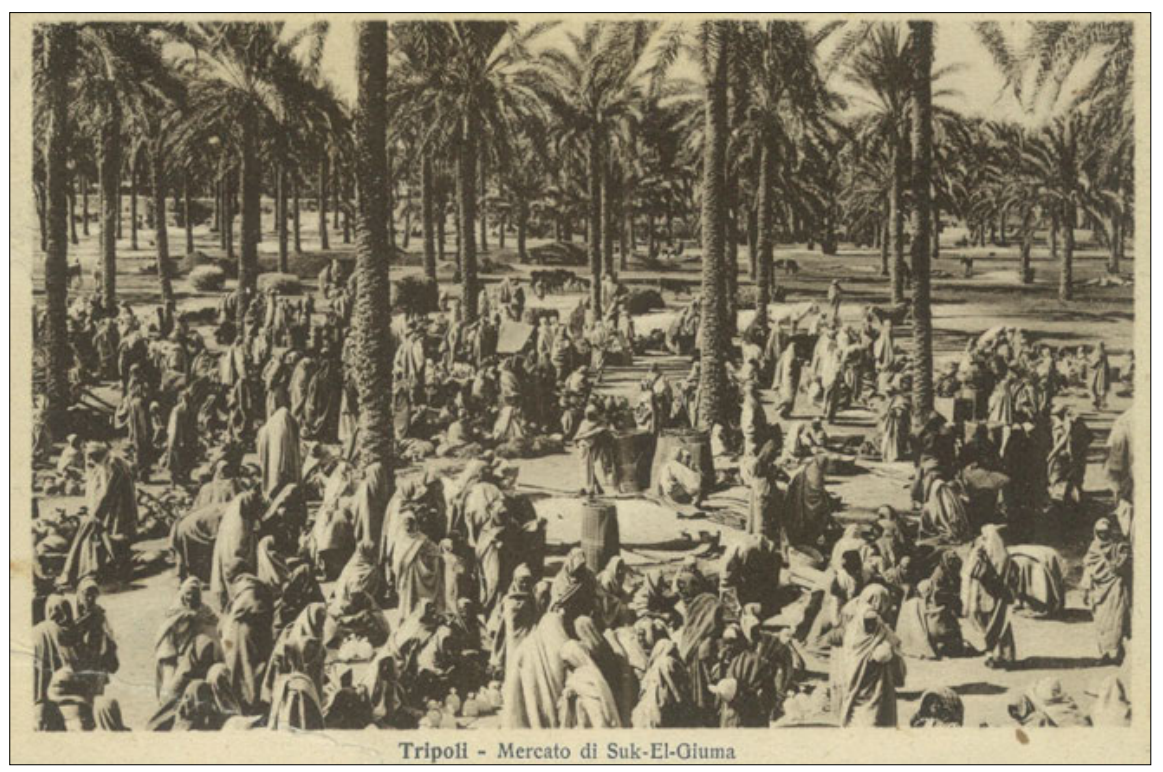

Picture 2: Friday market in Tripoli city in 1900

150 Jūbran, Mofīdā, al-'Aswāq bī-al-madīna al-qadīmah Ițrābulis dirāsā tārīkhiyya iqtișādīyya, mashrū' tanẓīm wa idārat al-madīna al-qadīmah Ițrābulis, Ṭarābulis, 2001, p. 53.

151 Kūrū, Lìbiyā athnā' al- 'ahd al- 'ūthmānì al-thānī, p. 78.

152 Wathā'iq Dār al-māḥafūḍāt al-tārīkhiyya al-Sarāya al-Ḥamrā', Ṭarābulis.

153 Ibn Mūsā, al-Mujtama' al-'arabì al-lībì, p. 193. 
The goods sold were mainly food and the daily necessities, as well as agricultural products such as cereals like wheat, as well as the sparto or halfa plant, dates, olive oil, fruits and other products. There was also a trade in livestock such as sheep, cattle, goats, camels and horses. ${ }^{154}$ The most important livestock markets in the city of Tripoli were al-Halfa and al-Khubuz. Both were weekly markets held on Mondays. The most important livestock markets not in the city of Tripoli were in the western part of the province, which were dedicated to the buying and selling of cattle. For instance, the market in the city of Gradates was located in the city center in an open area. There were 33 shops for selling different types of goods as well as other service shops. In the $19^{\text {th }}$ century, this market had developed and become a big market that included smaller specialized markets such as the livestock market, the artisan market and the market of the goldsmiths and other goods. ${ }^{155}$ In addition, famous markets were also held in al-Zawiya and Zuwarah in the western part of the province. In the central area of the province of Tripoli, markets were held in Ghadames, Ghat, Nalut and Murzuq in the south. Specifically, there was a larger market in Murzuq. ${ }^{156}$ In the eastern part of the province, Benghazi was able to take a privileged position after it became the capital of Cyrenaica mutașarrifizyya, and it became the center of trade. In Benghazi, markets were divided into two types. In the first, shops had ceilings and traded in goods like grain, food, silk and cotton clothes, along with weapons and several other minor commodities. The second type was open and consisted of standing stalls. The livestock trade took place daily, and was described as the most important trade in the state. ${ }^{157}$ The best-known livestock markets were found in Ajdabiyah, Suluq, and al-Marj. ${ }^{158}$ Foreign trade was significant for the economy of the province. This trade derived its wealth from two main sources: Caravan trade with sub-Saharan Africa and Arab and Ottoman provinces on one hand, and trade with European countries on the other. The Ottoman Empire had a high share in these exchanges as it imported tobacco, household tools, alcohol, rice, flour, textiles, mats, hinnah, ghee, oil, dates, and sponges. ${ }^{159}$

154 Ibrāhīm, “Anmāṭ al-tijārā al-dakhīliyya fĩ wilāyāt Ṭarābulis al-ghārb”, pp. 401-402.

155 Fātima al-Ma' lūl, madīnat Ghadāmis, pp. 41, 60.

156 al-Ḥashā’ishī, Moḥammad bin 'Uthmān, Riḥlat al-Hashā'ishī ilā Lìbiyā 1895 (Jalā' al-Karab 'an Ṭarābulis al-ghārb), ed. by 'Alī Mușțafa al-Mișrātī, Dār Lubnān li-l-țibā'a wa al-nashr, Bayrūt, 1965, pp. 85, 112.

157 Kākiyā, Lìbiyā fĩ al-' 'ahd al-' 'ùthmānī al-thānī, p. 125.

158 Kūrū, Lìbiyā fĩ al-'ahd al- 'ūthmānī al-thānī, pp. 79-80; Ibn Mūsā, al-Mujtama' al-'arabì allībī, p. 171.

159 Nājī, Tārīkh Ṭarābulis al-ghārb, p. 59; Kūrū, Lībiyā athnā' al-'ahd al-'ūthmānī al-thānī, p. 77; Ibn Mūsā, al-Mujtama' al- 'arabì al-lībì, p. 12. 
Many governors of the province of Tripoli focused on trading with countries located on the Mediterranean Sea according to the diversity of goods and financial return generated. The exchanges or transactions, especially with European countries, took place in Tripoli; they had to be approved by the Ottoman government. To facilitate these exchanges, the Ottoman government in the province of Tripoli opened transportation lines subjected to specific laws and regulations benefiting Ottoman trade and the economy. There was maritime commercial activity between Tripolia and some European countries. The German line (Deutsche Levante-Linie), for example, was one of the most important shipping companies transporting materials and products from and to both Germany and Belgium. ${ }^{160}$ Goods were transferred from the ports of Tripoli to others, such as Beirut and ports in Egypt. This was in addition to the Italian public navigation lines that were supervised by the Bank of Rome, which had taken the port of Genoa as its center of operations. This choice was mainly because Genoa was one of the main Italian ports and the one with the best connections to Tripoli and Benghazi. Its importance is also reflected by the fact that Genoa was the main port used for transit trade, specifically for those goods coming from Spain and Switzerland and sometimes from Germany. Maltese ships also contributed to this trade; the main operations took place between Marseille and the ports of Tripoli. Trade links with the ports of Tunisia were also established. ${ }^{161}$

As for Britain, the state benefited from the services of the Italian ships, in addition to using its own ships. At the same time, Great Britain sought concessions from state authorities to facilitate its trade with Tripoli, and succeeded in doing so in the $18^{\text {th }}$ century. As a result, they signed an agreement to ensure their export against in exchange for a few paid annually to the government in Tripoli. They were followed in this by Venice, while Russia failed to achieve the same end. ${ }^{162}$

160 See for example the archive of the Chambre de Commerce Marseille and see also the seminal work of Martel, André, Les confins Saharo-Tripolitains de la Tunisie, op.cit; see also Kūrū, Lībiyā athnā' al- 'ahd al- 'ūthmānī al-thānī, p. 76.

161 Kūrū, Lìbiyà athnā' al- 'ahd al-' 'ùthmānì al-thānī, pp. 74-75, 78.

162 Qaddūrā, Zāhiyyā, Tārīkh al-'arab al-ḥadìth, Dār al-nāhaḍa al-'arabiyya, Bayrūt, 1985, p. 417. 


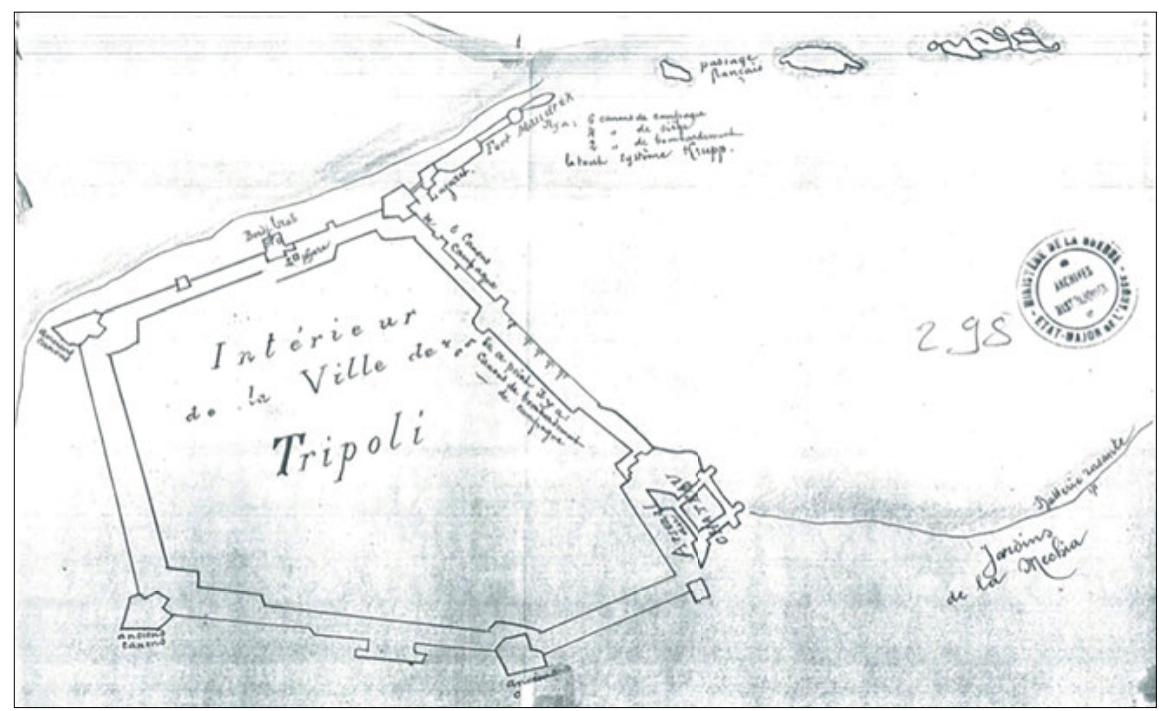

Map 4: Port city of Tripoli

France had sought to take advantage of this important convoy trade, actively working to extend its control over the most vital routes, especially in the border region between Tripoli and Tunisia ${ }^{163}$ and used these routes to serve their interests. They tried to change the routes to pass through Tunisia and Algeria instead of the province of Tripoli. They offered some privileges to traders to attract their attention and entice them to take these new trade lines. Their actions affected business in Tripoli, and resulted in the clear decline in operations at the end of the $19^{\text {th }}$ century. ${ }^{164}$ The attempt by France in 1880 to control the border area between Tripoli and Tunisia is also relevant to this discussion. ${ }^{165}$ The French ambitions were based on the strategic importance of this area and their own desire to take advantage of the caravan routes there. Some French officers and experts were thus sent to this region secretly. ${ }^{166}$ The Tuareg tribes in the southern part of the province of Tripoli, and in the context of conflict with other tribes such as the Hagar in 1898, were suspicious of all these movements in the border area. Their suspicion led them to oppose the judge (the document does not mention

163 Martel, Les confins Saharo-Tripolitains de la Tunisie, p. 180.

164 Ḥamīda, al-Mujtama' wa al-dawlā wa al-isti 'mār fĩ Lībiyā, p. 93.

165 See for example Pervinquière, Léon, Tripolitaine interdite Ghadamès, Nabu Press, 2011, p. 336. 166 Martel, Les confins Saharo-Tripolitains de la Tunisie, p. 180. 
his name) of Tataouine city (in the province of Tunis), which was located near the western border with Tripoli. The judge was almost killed by the Tuareg when he arrived in Ghadames in 1898, as part of a publicity campaign to support the French at the expense of the Ottomans. ${ }^{167}$ But the mayor of Ghadames was able to stop them and informed them of the serious consequences of such an act on the relationship between Tripoli and France. When this news reached the governor of Tripoli, Namik Pasha ordered the release of the judge and sent ten guards to protect him until he arrived in Tataouine. ${ }^{168}$ In 1898, a small group of French soldiers crossed the provisional Libyan-Tunisian border that had been established by the colonial powers and traveled 20 miles into Libyan territory. The unit established a military camp within the French colonial borders of the province. ${ }^{169}$ The Ottoman state did not accept this and demanded the appointment of a committee to determine the zones of influence and to mark the borders accurately. ${ }^{170}$

The province of Tripoli had benefited greatly from the sparto (halfa) trade, as one of the main sources of revenue, especially in the $19^{\text {th }}$ century. It boomed in $1896^{171}$ and the largest importer was Britain. The price per quintal amounted to seven pounds. The sparto was cultivated in different areas such as Jifarah, Tarhuna, the mountain area, al-Aeaiat, Warshefana, Meslata, al-Amamra and others. ${ }^{172}$ The province's authorities were concerned with this production; in the mid-19 ${ }^{\text {th }}$ century, machines were used to compress the sparto into bundles or bales ready for storage or transportation in the center of the province and in cities like alKhums ${ }^{173}$ and Benghazi. Later, the cities producing this product were increasingly located between al-Aziziyah and al-Khums. ${ }^{174}$ The supervisors of the machines were under the direct control of the government who seriously controlled for any manipulation in the production process. For instance, a manuscript referred to an act of embezzlement in al-Khums. It mentions that a director was involved. This

167 Politisches Archiv des Auswärtigen Amts, Allgemeine Angelegenheiten, Bd. 6-7, vom 1. Mai 1895 bis 31. Januar 1899, R16111, .

168 Ibid.

169 On this issue see the colonial borders of the region (see map in the annex).

170 Politisches Archiv des Auswärtigen Amts, Allgemeine Angelegenheiten, Bd. 1, 1895 bis 1899, Nr. A12804, R16111.

171 'Ughlī, Khalīl Sāḥlī, "al-Mașādir al-muta'aliqa bi-lỉbiyā fī maktabat jāmi'at Isțanbūl”, $M a$ jallat al-buhūth al-tārīkhiyya, 2-2, markaz jihād al-lībīyyīn li-l-dirāsāt al-tārīkhiyya, Ṭarābulis, 1980, p. 250.

172 Mangano, G., L'Alfa in Tripolitania, Firenze, Milano, pp. 5-6.

173 Nājī, Tārīkh Ṭarābulis al-ghārb, p. 32.

174 Ibid., p. 73; Kūrū, Lìbiyā athnāa' al-'ahd al-'ūthmānī al-thānī, p. 70. 
forced the administrator to write to the governor immediately. ${ }^{175}$ Even the process of collecting the plant from the fields and transporting it to the city of Tripoli was controlled and supervised by the Tripolitan authorities. Nevertheless, the accumulation of the crop in front of stores resulted in an obstruction of traffic in some streets, prompting the city council to address the ruling authorities about three crucial issues: the blocking of the traffic, the threat of fire that might lead to serious consequences, and the camels used to bring the crop and which stayed there for some time, which had its own disadvantages. The main request of the city council was to locate the market for the crop outside of Tripoli. ${ }^{176}$ There were many companies involved in exporting the sparto, for example Arbeeb, the Bank of Rome, Perry Puri, H.B. Nahum, and M.J. Hassan. Each of these companies had compressing laboratories and storage facilities, especially, Arbeeb and Nahum in the cities of Tripoli and al-Khums, al-Tabya and Zlitan. Puri and Hassan only stored the plant in Tripoli and al-Khums. The main crop markets were in the cities of Tripoli, al-Khums and Zlitan. ${ }^{177}$ The revenues from exporting the sparto varied from year to year. For instance, it was 4.000 Francs in 1870, but it increased in the subsequent years to reach 3.750.000 Francs. ${ }^{178}$ The Ottoman documents show that the amounts exported in 1895 were equivalent to 53.855 Ottoman qirsh and in the next year the value was only 49.318 Ottoman Qirsh. ${ }^{179}$ The authorities in Tripoli started to focus their efforts on increasing production and they decided to form a committee composed of the mayor of Tripoli, engineers, the head of the port, the head of the sailors and some traders. The main mission of this committee was to select a suitable place for establishing a new port dedicated specifically to the export of this plant. ${ }^{180}$ This was an important step taken by the Ottoman government and indicated the economic significance of this plant for the province of Tripoli. Sponge was the second main export of the province of Tripoli due to the demand for this product in European countries. Greek sailors were the main traders of this product. There were some Greeks living in Tripoli, and some of them were traders. The sponge that was found alone the coast of Cyrenaica

175 Wathīqā 4/2/1052, 1896, Milaf buḥūth wa maqālāt (nabāt al-ḥalfa), al-markaz al-wațanī li-lmāḥafūụāt, Ṭarābulis.

176 Wathīqā 105/2/4 Māyū 1871, Milaf buhūth wa maqālāt (nabāt al-ḥalfa), al-markaz al-wațanī li-l-māḥafūḍāt, Ṭarābulis.

177 Mangano, L’Alfa in Tripolitania, 1913, p. 38.

178 Nājī, Tārīkh Ṭarābulis al-ghārb, p. 33.

179 Wathīqā 1051/2/4, 1318, Milaf buḥūth wa maqālāt (nabāt al-ḥalfa), al-markaz al-wațanī li-lmāḥafūụāt, Ṭarābulis.

180 Wathīqā 2011, 1875, Milaf buḥūth wa maqāāāt (nabāt al-ḥalfa), al-markaz al-wațanī li-lmāḥafūụāt, Ṭarābulis. 
was of the highest quality. ${ }^{181}$ Ostrich feathers and ivory were imported from subSaharan Africa and were also very significant exports that played an important role in the economy of the province of Tripoli. These products also attracted the attention of the European traders, which led them to travel to the province to bring goods in high local demand, which they would then exchange for the domestic goods and other goods coming from Africa. ${ }^{182}$ The province used several ports to export and import ostrich including the port of Tripoli, which was where most of the trade with Europe took place. This was in addition to the other five ports of al-Khums, Zlitan, and Misurata, Derna and Tobruk and other smaller anchors. Trade with Germany was carried out by the German shipping line (Deutsche Levante-Line). Various categories of goods were imported from Germany including haberdashery, blankets, tea, sugar, iron, glass, perfumes, chemicals and medical materials, textile yarns, ropes, cotton, wool textiles, porcelain, gold and silver ornaments, and alcohol. ${ }^{183}$ Exports to Germany focused on leather, ivory, ostrich feathers, barley, salt and dates. Goods imported from Germany tended to be transported to Malta first and then to Tripoli and Benghazi by the Italian shipping lines. ${ }^{184}$ The reports of the English consul contain important information about the volume of trade exchange between the province of Tripoli and different European countries focusing on Germany. For instance, one report states that the year 1884 could be considered the actual beginning of commercial traffic from Germany. In terms of trade, Germany was ranked $6^{\text {th }}$ on the list of countries for both import and export to and from the province of Tripoli. This rank increased or decreased depending on the quantity and quality of the products. In 1888 and 1889, for example, Germany was ranked in the seventh place and in 1893 in the eighth place, when the German imports from Tripoli were estimated to constitute a value of $€ 7.000$. In 1894, German imports were valued more modestly at $£$ 4.000. German exports from Tripoli amounted to £16.000 in 1893 and increased to $£ 27.500$ in 1894 . ${ }^{185}$ The amount was the same in 1895 despite the decrease in the quantity of imported goods. In 1895, the quantity of the imported goods

181 Kūrū, Lībiyā athnā' al- 'ahd al- 'ūthmānī al-thānī, p. 71-72; 'Āmir, Tārīkh al-maghrib al arabī, p. 156.

182 'Āmir, Tārīkh al-maghrib al 'arabì, p. 157.

183 Bundesarchiv, Die Handels- und Schifffahrtsverhältnisse mit Tripolis, Bd. 1, vom Juni 1884 bis Oktober 1904, 901/11936; Kūrū, Lìbiyā athnā' al-'ahd al-'ūthmānī al-thānī, p. 77; Nājī, Tārīkh Țarābulis al-ghārb, pp. 55-56.

184 Kūrū, Lìbiyā athnā' al-' 'ahd al- 'ūthmānī al-thānī, p. 77; 'Ughlī, "al-Mașādir al-muta'aliqa bi Lībiyā”, p. 254.

185 Bundesarchiv, Die Handels- und Schifffahrtsverhältnisse mit Tripolis, Bd. 1, vom Juni 1884 bis Oktober 1904, R901/11936, Nr. II 11590. 
was $£ 4.000$ while the exported goods reached a value of $£ 29.000 .{ }^{186}$ Generally, in these reports Britain was at the top of the list of European countries involved in trade with the province of Tripoli. The most important product exported to Britain was the sparto (halfa). The earnings from export of this plant reached 2.500 .000 French francs, in addition to the earnings from exporting ostrich feathers and ivory. ${ }^{187}$ On the other hand, merchants brought tea, aromatic and medicinal chemicals and paints, ropes, cotton textiles, woolens, iron, and some minerals and other miscellaneous goods from Britain. ${ }^{188}$ France and Italy came next in rank, with almost the same goods. The differences are in those goods imported from the European countries. ${ }^{189}$ There was also significant trade with other countries such as Malta, Greece, Spain, the United States and Austria. ${ }^{190}$

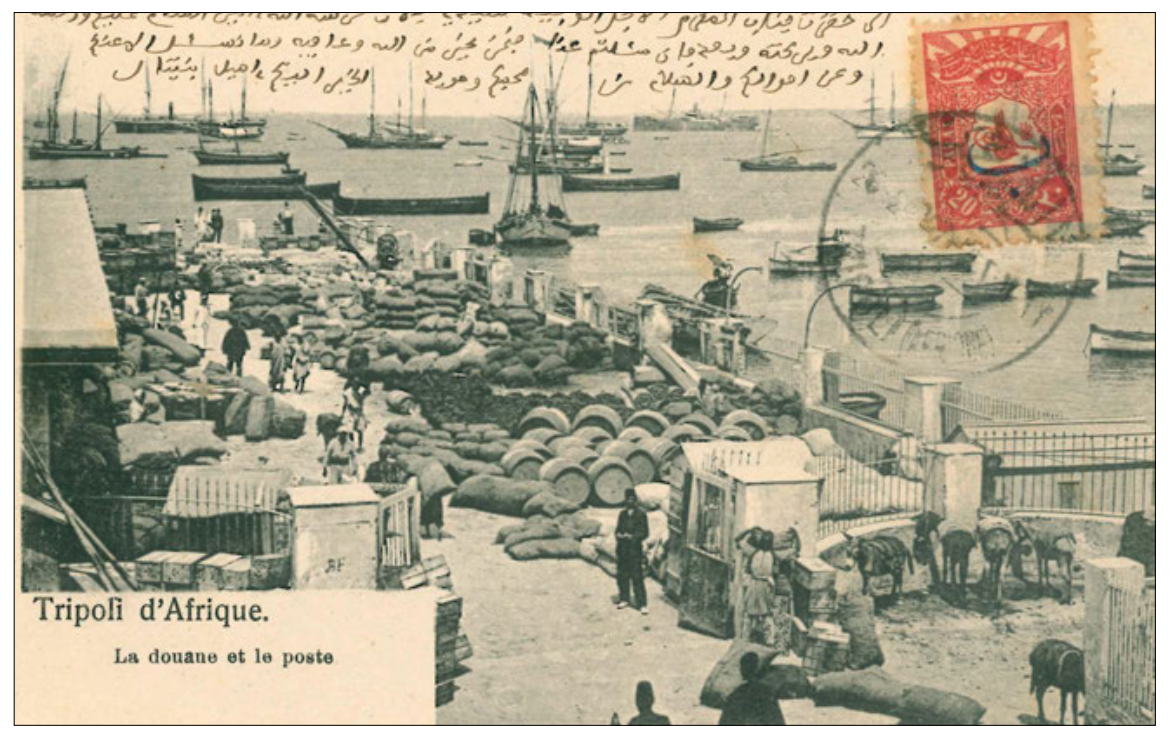

Picture 3: Goods in the port city of Tripoli and customs

186 Bundesarchiv, Die Handels- und Schifffahrtsverhältnisse mit Tripolis, Bd. 1, vom Juni 1884 bis Oktober 1904, R901/11936, Nr. 27611/96.

187 Nājī, Tārìkh Ṭarābulis al-ghārb, pp. 59-72.

188 Ibid., pp. 53-54.

189 Kūrū, Lìbiyā athnā̄' al-' 'ahd al- 'ūthmānī al-thānī, p. 75.

190 Nājī, Tārīkh Ṭarābulis al-ghārb, p. 59; Ibn Mūsā, al-Mujtama' al-'arabī al-lībì, p. 191; the trade with Germany will be discussed in more details in chapter 3 of this study. 
Concerning the slave trade, an important one reached its peak during the second half of the $19^{\text {th }}$ century. The slaves were used locally as domestic workers and in farms where (halfa) was planted and cultivated. Slaves were also moved from Borno to Fezzan, from there to Tripoli, and from there they were sent abroad, particularly toward Anatolia. ${ }^{191}$ As for the trade line, it was as follows: TripoliBenghazi, Alexandria, then to the Ottoman cities like Romelia, Anatolia, Istanbul and Salonik and other places. ${ }^{192}$ This was before the decision to ban the slave trade (see Map 5).

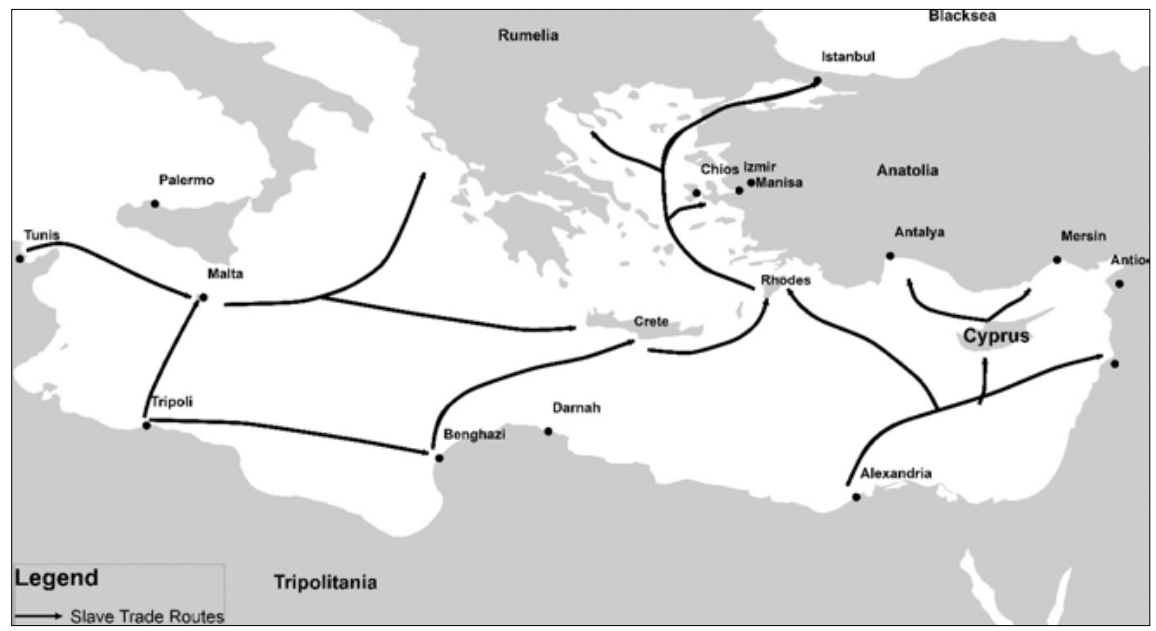

Map 5: Slave trade lines and routes in 1850

Ghadames was also a place for buying slaves coming from West Africa. Some Ottoman slave traders would travel directly to Ghadames to sell their slaves there. Meanwhile, the traders in Benghazi tended to go to Murzuq to buy slaves. These traders also went to the center of Tripoli.

The province of Tripoli made a huge economic boom in the slave trade. However, Europe began to fight the slave trade after the second half of the century and held several conferences to intensify their efforts to stop it. Britain, with ambiguity led efforts to stop the slave trade completely, especially in the provinces controlled by the Ottoman Empire in North Africa and other regions. It

191 Rāfiq, al- 'Arab wa al- 'ūthmānīyyūn, 1516-1916, p. 161; Nājī, Tārīkh Ṭarābulis al-ghārb, p. 67. 192 Toledano, Ehud R., The Ottoman Slave Trade and its Suppression: 1840-1890, Princeton University Press, New Jersey, 1982, pp. 41, 47. 
succeeded in convincing the Ottoman Empire to declare the permanent cessation of the slave trade in $1857 .{ }^{193}$ Tunis was one of the first regions to abolish it in 1846. The Ottoman Empire then sent orders to the province of Tripoli stating the need to stop the slave trade. These orders were circulated among traders especially, those who used to trade between Tripoli and the city of Kano, where the slave trade was directly affected by these orders. Severe penalties were issued for violating those orders, and historical documents refer to the punishment of seven years' imprisonment for the sale of slaves and fourteen years for their purchase. ${ }^{194}$

The slave trade was among the important trade activites in the North African states; this means that this policy and the British efforts to stop slave trade more widely caused significant damage to the structure of the economy, and led to the decline in annual revenues and a clear lack of financial resources. However, Britain was aware that the prohibition of the slave trade allowed British authorities to impose restrictions on the leaders of the African tribes and the governors of the provinces there. ${ }^{195}$ Despite all these efforts, the slave trade did not stop at once, rather, it continued for some time. This is revealed in some European correspondence on this subject, ${ }^{196}$ for instance, the messages sent by the German explorer Gerhard Rohlfs, who was in Murzuq in $1865^{197}$ and the Italian agents working for the Ministry of Foreign Affairs to the Italian ambassador in Constantinople to inform him that the slave trade continued in the port of Benghazi, and was under the protection of senior Turkish officials there. ${ }^{198}$ It is argued in the literature that the slave traders circumvented the authorities in order to continue their trade. ${ }^{199}$ They would work in secret, anchoring their ships a short distance outside Istanbul to avoid discovery and bring the slaves into the city during the night. The transactions were carried out quickly and sometimes the traders would sell the slaves on board for fear of being discovered. ${ }^{200}$ To distract the attention

193 On this trade see the work of Toledano, The Ottoman Slave Trade.

194 Yūsha', Wathā’iq Ghadāmis, Wathīqā 12 risālā min Moḥammad al-Ṣaghīr bin Moḥammad alṬhinì ilā Mohammad al-Ṣaghīr Hì̃dāh fì Kānū, 1856.

195 al-'Abīdī, Jāsim Mohammad Shațab, "al-Nufūdh al-birīṭānī wa tijārat al-raqīq fī al-khalīj al'arabī fī al-qarn al-tāsi' 'ashr”, Majallat al-buhūth al-tārīkhiyya, 26-2, markaz jihād al-lībīyyīn dị al-ghazū al-iṭālī, jāmi 'at al-Fātiḥ, Ṭarābulis, 2004.

196 Boubaker, Sadok, “Considérations sur le rachat des'esclaves' de la course à Tunis à l'époque moderne, in Corsari, schiavi, riscatti tra Liguria e Nord Africa nei secoli XVI e XVII, Comune di Ceriale, 2005, pp. 159-167.

197 Rulfis, Riḥla ilā al-Kufrā, p. 204.

198 Wathīqā 879, Mursala min wizārat al-shu'ūn al-khārijīyyā ilā safīr Ițalī bi-l-Qusțanțīniyya, 18 Uktūbar 1907, milaf tijārat al-raqīq, al-markaz al-wațanī li-l-māḥafūọāt, Ṭarābulis.

199 Rūsi, Lībiyā mundhu al-fath al'arabì, p. 379.

200 Ibid. 
of authorities they would also move in small groups. From Istanbul, the slaves were sent to Egypt and Malta. A conference was held in Brussels, Belgium, in 1890 to eliminate this trade and a committee was commissioned to stop slavery in 1891. It worked with a group of people in secret to detect and prevent traders from continuing the slave trade. ${ }^{201}$ The committee assigned Carlo da Borgo to guard the coast of Tripoli to control the passage of any ships carrying slaves, even as gifts sent to the Ottoman sultan in Constantinople. ${ }^{202}$ In the same context, stricter control measurements were also discussed at the conference. A report from Carlod da Borgo, who was then living in Tripoli, was presented to the committee. This report shows the number of convoys carrying slaves from June 1907 through June 1908. ${ }^{203}$ According to the statistics, the number of slaves who entered the province reached about 550. One convoy carried 80 slaves; this convoy arrived in Tripoli on March 18, $1908 .^{204}$ As a result of this report, the activities to liberate slaves were intensified and manumitted slaves were hosted in certain places until they were able to manage their own lives. ${ }^{205}$ Examples of these activities were conducted by the English consul in Benghazi and the Italian consul in the city of Tripoli, especially at the end of 1878, when help was offered to liberate slaves to improve their situation. It is stated that, from 1878 to 1879,12 slaves were liberated by the Italian consulate. ${ }^{206}$

Ettore Rossi indicates that the first identification of the population of Tripoli was in the $10^{\text {th }}$ century BC. ${ }^{207}$

The inhabitants of the province of Tripoli can be divided via geography into urban, rural, desert nomad populations. Some scholars indicate that the popula-

201 Ibid., p. 381.

202 Wathīqā 36, Mursala min mas'ūl murāqabat murūr al- 'abīd bi al-sawāḥil ilā wazīr al-shu'ūn al-khārijīyyā bi Rūmā 19 Māyū 1907, Milaf tijārat al-raqīq, al-markaz al-wațanī li-l-māḥafūọāt, Ṭarābulis; see also Boubaker, Sadok, Réseaux et techniques de rachat des captifs de la course à Tunis au XVII e siècle, in Le commerce des captifs. Les intermédiaires dans l'échange et le rachat des prisonniers en Méditerranée, XVe-XVIIIe siècle, Etudes réunies par Wolfgang Kaiser, Ecole Français de Rome, 2008, pp. 25-46.

203 Boubaker, Réseaux et techniques de rachat des captifs de la course à Tunis au XVIIe siècle, pp. 25-46, op.cit.

204 Wathīqā 8, Mursala ilā al-mu’tamar al-diblūmāsī fì Brūksil 1908, Milaf tijārat al-raqīq (al-istirqāq fī Ṭarābulis al-ghārb wa Barqa 1907-1908), al-markaz al-wațanī li-l-māḥafūụāt, Tarābulis.

205 Wathīqā 39, 26 Dīsambir, al-markaz al-wațanī li-l- wathā’iq wa al-makhțūṭāt, Ṭarābulis, 2004. 206 Aḥmed, Khalīfa Ibrāhīm, Tijārat al-raqīq fī wilāyāt Ṭarābulis al-ghārb khilāl al-qarn al-tāsi 'ashar, al-markaz al-wațanī li-l-māḥafūḍāt, Țarābulis, 2014, p. 184.

207 Rossi, Etore, Storia di Tripoli e della Tripolitania dalla conquista araba al 1911, Istituto per l'Oriente, Roma, 1968, p. 25. 
tion of Tripoli is descended from the Upper Nile region and belongs to the Hamitic group, while others point out that they arrived from the southern Arabian Peninsula and thus are Semites. ${ }^{208}$ A small group of historians attributes its origins to the Mediterranean region, ${ }^{209}$ whereas there are also references made to groups referred to as Libyan tribes living in the region during this period. Still, there is no consensus about where these tribes came from. It is revealed in the literature that the city of Tripoli and the rural areas of Tripoli maintained their social structure throughout the rule of the Ottomans and were not significantly influenced by the so-called Turkish customs or social practices. ${ }^{210}$ These were considered by many people as "alien" to the society. ${ }^{211}$ Another factor that contributed to the continuance of local social norms was that the Ottoman rulers tended to focus on aspects relating to political power and having the region submit to their administration. They did not intervene to change the local social and cultural structure. Thus, the society preserved its structure, particularly in the rural and nomadic areas. ${ }^{212}$

Social structure was described by some historians as homogeneous in terms of three factors. ${ }^{213}$ The first of these was its characterization as tribal and the importance of tribal relations in preserving social bonds. Second, the society was predominantly Muslim and the majority of the population followed the Maliki School, with the exception of the population of the western mountain and Zuwarah, who belonged to the Ibadi School. Finally, Arabic was the principle language. ${ }^{214}$ However, beyond these three shared characteristics the population was also very diverse and the result of centuries of mixing. One factor was the existence of different ethnic groups, including indigenous inhabitants based mostly in the mountains, the central part of the province, and the coast. Centuries later, mixed situations were most common. A part of the population arrived in the province from Andalusia at the time of the reconquista and the expulsions that followed. Among them were both Muslims and Jews. There were also Jewish populations prior to the influx from Andalusia adding to the community of local

208 Ibid.

209 Ibid.

210 Ibn Mūsā, al-Mujtama' al-'arabī al-lībī, p. 25.

211 Ibid.

212 Rūsi, Lìbiyā mundhu al-fath al 'arabì, p. 388.

213 al-Shīkh, Ra'fat Ghunīmī, "al-Ḥayāt al-ijtimāēìyya fī wilāyāt Ṭarābulis al-ghārb al-'ūthmānīyyā fī al-'așr al-' ūthmānī al-akhīr (1835-1911)”, al-ḥayāt al-ijtimā 'ìyya fì al-wilāyāt al- 'arabiyya athnā'al-'ahd al'uthmānī, vol. 1-2, intr. by 'Abd al-Jalîl al-Timīmī, markaz al-dirāsāt wa al-buhūth al-'ūthmānīyyā wa al-mūrīsikīyya wa al-tawthīq wa al-ma' lūmāt, Zaghwān, n.d., p. 411.

214 Ibid. 
Jews from Tripolitania. Later, more Jews came from other regions in the Ottoman Empire and the Mediterranean. The Berber population included both Muslims and Jews, although Muslims predominated. Many Jews in Tripoli lived in a specific part of the city referred to as hāra al-Yahūd (the quarter of the Jews) ${ }^{215}$ but other Jews lived in the mixed quarter and it was not as clearly cut as generally described by European travelers. Indeed, these often speak of the existence of separate quarters. But there were also mixed quarters where Jews and Muslims lived together. Statistics indicate that during the second Ottoman period (18351911) the number of Jews reached a quarter of the population (14.142 persons in the province of Tripoli). It is said that they mainly lived in the coastal cities, but this was not the reality. ${ }^{216}$ Most of the population were the result of intermarriage between local women and men from outside the region, as in the case of the Kwärghlìyya. These were the sons of Ottoman officers of diverse origins who married women from Tripoli. ${ }^{217}$ There were also populations originating from the South, like the Toubou tribes. ${ }^{218}$ Diverse Saharan and sub-Saharan populations were also present. Representatives and officers of the Ottoman Empire were part of the ruling stratum in Tripoli along with local notables. ${ }^{219}$ They had very diverse origins: Turkish, Greek, Arab, Caucasian, Albanian, Serb, Circasian, Tatar and Kurd. In the harbor, there were also populations of converts (Sards, Sicilians, Maltese, etc.). There were also foreign merchants, prisoners and navy operatives. A group of Italian Jews from Livorno (Granata) were among the most active merchants. ${ }^{220}$ Jewish merchants often traveled with merchant caravans ${ }^{221}$ and owned workshops manufacturing jewelry from gold and silver. ${ }^{222}$ In addition to all these groups, the presence of the Italians in Tripoli was a long-standing one. Some

215 De Felice, Renzo, Jews in an Arab Land Libya, 1835-1970, University of Texas Press, Austin, 1985, p. 406.

216 Zorzi Tavanelli, a Venitian captain, was taken at sea by Tripoli pirates, sold to Jewish and Muslim merchants with his companions, and then ransomed through the intercession of the consuls of France and Sweden. He states that in 1749 Tripoli had sixteen to seventeen thousand inhabitants, almost half of them Jewish. This estimate is certainly too high. Another Venitian, the merchant Mariano Doxera, was probably closer to the mark in 1783 when he spoke of a population of about forteen thousand, including about three thousand Jews "who, as in the other cities of Africa, are employed in trade and wear distinctive dress", De Felice, Jews in an Arab Land Libya, op.cit, p. 7.

217 Baladiyyat Țarābulis fì mā'at 'ām 1286/1391H - 1870/1970M, p. 412.

218 Kūrū, Lībiyā athnā' al-'ahd al-'ūthmānì al-thānī, p. 17.

219 al-Shīkh, “al-Ḥayāt al-ijtimā 'īyya fĩ wilāyāt Ṭarābulis al-ghārb”, p. 416.

220 al-'Aḥwal, “al-Jāliyāt al-ajnabīyya fī Lībiyā 1835-1950)”, p. 29.

221 Stein, Sarah Abrevaya, Falling into Feathers: Jews and the Trans-Atlantic Ostrich Feather Trade, Journal of Modern History, 79-4, 2007, pp. 772-812.

222 Ibid. 
historians argue that the Italian presence in Tripoli goes back to the Roman Empire, when they came as traders and craftsmen. ${ }^{223}$ After Italian unification in 1870, the number of Italians in Tripoli increased. They started entering the province as immigrants and emigration reached its highest levels between 1885 and $1890 .{ }^{224}$ The migration of the Italians continued, and they managed to establish large-scale economic projects, especially after the opening of the Banco di Roma in 1905, and their influence obviously increased after the Italian occupation of the province. The Italian presence there included a significant number of Maltese. Their sizeable presence can be attributed to the proximity of the countries and the ease of travel between them. ${ }^{225}$ The Maltese started to move to the province of Tripoli, where they built their own neighborhood, known as the Maltese quarter, in the city of Tripoli. In 1882, their number was 2.000 persons and this rose in the following years to over 3.000. They were also successful traders and benefited by being under the protection of the English consulate. ${ }^{226}$ Alongside the Maltese and the Italians, there were other smaller communities such as the Jewish-Austrian community, which numbered 105 people. ${ }^{227}$ The French community consisted of approximately 564 people in Tripoli and 100 people in Benghazi. Approximately 100 Dutch were registered, some of them Jews. The Spanish community numbered 100 people in Tripoli and 50 people in Benghazi. The Greek community had 236 people ${ }^{228}$ whereas only 11 Germans were counted. Most of these communities gained a consul or representative for their interests in the province of Tripoli as it increased in size and significance. ${ }^{229}$ Another factor reflecting the heterogeneity of the society in the province of Tripoli is the significant disparity between the living standards of the inhabitants of Tripoli. The social structure reflected this stratification. At the top of the social pyramid were the rich or the politically powerful, alongside the most important religious scholars, the leaders of the school of Sufism (tarīqah Sufīya), which was a common phenomenon throughout the region in the $19^{\text {th }}$ century) as well as the judges. This stratum was followed by the small traders and then the craftsmen, which were in turn above the foreign communities. The lowest social stratum was made up by the servants and

223 al-'Ahwwal, “al-Jāliyāt al-ajnabīyya fī Lībiyā (1835-1950)”, pp. 160-161.

224 Ibid.

225 Lafi, Nora, Les relations entre Malte et Tripoli de Barbarie au XIXe siècle, R.E.M.M.M., 71, 1994, pp. 127-142; Fīru, al-Hawlīyyāt al-lībiyyā, p. 350.

226 al-'Aḥwal, “al-Jāliyāt al-ajnabīyya fī Lībiyā (1835-1950)”, p. 173.

227 Baladiyyat Ṭarābulis fī mā'at 'ām 1286/1391H-1870/1970M, p. 422.

228 Ibid.

229 Kūrū, Lìbiyā athnā' al-'ahd al- 'ūthmānī al-thānī, pp. 23-24. 
slaves. ${ }^{230}$ The basic unit of society was the family. This usually consisted of a father, a mother and their children living in one house, which was often composed of two floors. This house would be surrounded by other houses of the same size, which were occupied by members of the same extended family or tribe. ${ }^{231}$ With regard to holidays and celebrations, people in the province of Tripoli celebrated the Muslim festivals of Eid al-Fitr and Eid al-Aḍha just as in other Muslim countries. The birth of the Prophet was also an important celebration. These events were celebrated at both the official and the local levels. The people in the province of Tripoli also cared about social events such as marriage and others. ${ }^{232}$

Local people relied on the quranic education among othe knowledge provided in mosques and quranic schools for children, which focused on the memorization of the Quran and Sunna as well as the main principles of reading and writing. ${ }^{233}$ This model of education continued until the Ottoman government issued a number of decrees on education, including two resolutions issued and adopted in 1869 and 1871. Some governors, such as Ahmed Ezzat (second term 1879-1880), set up schools that followed modern methods of education. Following this, the modern form of schools spread more widely and by 1877 it covered the province as far as Murzuq. This was part of a policy pursued by the Ottoman Empire in the various Ottoman provinces. The policy was made in accordance with proposals submitted to the Ottoman Sultan Abdul Hamid II in 1869, which included the need to develop and organize education at various levels and to build schools that "corresponded" to the European model. In 1881, work on the practical implementation of the proposals seriously began. The work started by focusing on the elementary schools. The Ottoman government had developed a funding 1884 for construction and financing of the schools during the Tanzimāt period. ${ }^{234}$ Thus the number of schools was on the rise in all the provinces of the Ottoman Empire,

230 See Carr, William and Harry Hearder, The Wars of German Unification, London, Routledge, 2014, 254p; see also Nuwār, 'Abdul-'Azīz wa 'Abd al-Majīd Na'na 'ì,'Aūrūbbā min al-thawrā al-firinsīyyā, ilā al-ḥarab al-'ālāmìyyā al-thānīyya, Dār al-nāhaḍa al-'arabiyya li-l-ṭiba'ā wa alnashir, Bayrūt, n.d., p. 272.

231 al-Sanīnī, Miftāḥ Khalīl, al- 'Umarā' min ahl Barqa wa al-ṣaḥarā', Dār al-qimmah wa Dār al-imān, al-Qāhira 2011, p. 217

232 Ibn Mūsā, al-Mujtama' al-'arabì al-lībī, p. 25.

233 Belḥāj, Moḥammad al-Kūni, al-Ta līm fĩ madīnat Ṭarābulis fì al-'ahd al-'ūthmānī al-thānī 1835-1911 wa atharahu 'alā mujtama' al-wilāyā, markaz jihād al-lībīyyīn li-l-dirāsāt al-tārīkhiyya, Ṭarābulis, 2006, pp. 39, 43.

234 Evered, Emine O., Empire and Education under the Ottomans: Politics, Reform and Resistance from the Tanzimat to the Young Turks, London: I.B. Tauris, 2012, pp. 114, 116, 118. 
including Tripoli. ${ }^{235}$ After this, the provincial government in Tripoli established one industrial school in 1895 . The project was supervised by the administrative government in Tripoli and the governor Namik Pasha. The Hamidieh Industrial School was built in 1889, during the term of the governor Mohammad Hafiz Pasha. ${ }^{236}$ The teachers were Ottoman. ${ }^{237}$ The main teaching languages were Arabic and Turkish; Turkish having been introduced to the education system in $1890 .{ }^{238}$ The Ottomans were also concerned with agricultural education, and in 1909 the council of the province issued a decree for the establishment of an agricultural school, along with the appointment of specialized teachers for its pupils. ${ }^{239}$ There were also a number of developments in terms of the media; newspapers were introduced for the first time, with first newspaper issued in the second half of the $19^{\text {th }}$ century under the title West Tripoli. Historical sources give differing information regarding the date of its publication. According to some, it was published for the first time in $1866,{ }^{240}$ whilst others maintain that it was issued in $1871 .{ }^{241}$ It was a four-page official weekly newspaper in Arabic and Turkish and printed in the province. It was issued after the publication order of Sultan 'Abdul- 'Azīz. This first newspaper was issued mainly to publish the Sultan's orders, directives and declarations and continued until the entry of the Italian colonialists in 1911, when the printing press was destroyed by bombs. Other newspapers were also issued that had a significant role in spreading culture and information to the population. One example of these newspapers was al-Taraqī, issued in 1897 by Mohammad al-Buṣayrī. These newspapers existed before the Young Turks achieved power in the Ottoman Empire. The most well-known newspapers that emerged during the rule of this group were: al-'Asr al-Jādìd, which was issued in 1909, al-Merșād, Abugasha and al-Raqyyīb, all of which were issued in 1910, and al-Dārdānīl in

235 Ibid., p. 124.

236 Baladiyyat Țarābulis fì mā'at 'ām 1286/1391H-1870/1970M, p. 87.

237 al-'Āqil, Aḥmed Moḥammad, “al-Ta'līm al-ḥadīth fī Lībiyā khilāl al-fatra (1835-1950)”, alMujtama' al-lībī (1835-1950), a'māl al-nadwā al-'ilmiyya al-thāmina allatī 'uqidat bi-l-markaz fī al-fatra min 26-27/9/2000, ed. by Moḥammad al-Ṭāhir al-Jarārī, markaz jihād al-lībīyyīn li-ldirāsāt al-tārīkhiyya, Țarābulis, 2005, pp. 523, 525.

238 Ibid.

239 al-Ṭawīr, Moḥammad Aḥmed, "al-Zirā'a fī wilāyāt Ṭarābulis al-ghārb athnā' al-ḥukm al'uthmānī al-thānī al-mubāshir lahā 1835-1911”, al-Hayāt al-sīyāsiyya li-l-wilāyāt al-'arabiyya wa mașādir wathā'iquhā fì al- 'ahd al- 'ūthmānī, vol. 1-2, intr. by 'Abd al-Jalīl al-Timīmī, markaz al-dirāsāt wa al-buhūth 'an al-wilāyāt al-'arabiyya fĩ al-'ahd al-' ūthmānī, Zaghwān, 1986, p. 521. 240 Āarībī, Moḥammad al-Ṭāhir, Wathā'iq al-Sarāya al-Ḥamrā', al-Dār al-'arabiyya li-l-kitāb, Lībiyā - Tūnis, 1977, p. 47.

241 Tarāzī, Fīlīb Dī, Tārīkh al-ṣaḥāfa al- 'arabiyya, volume 2-4, al-mațaba'a al-adabiyya, Bayrūt, 1967, pp. 206, 240, 314; Baladiyyat Ṭarābulis fì mā’at 'ām 1286/1391H-1870/1970M, p. 416. 
$1911 .^{242}$ In addition, an annual volume was released by the Ottomans. Entitled the Salname, this contained the most important information about the province including its history and geography. ${ }^{243}$ The Ottoman province of Tripoli between 1870 and 1884 and its resources and raw materials made the province an explicit prize for the colonizing forces. At the same time, it is important to highlight the social structure and the cumulative cultural heritage that aided in resisting colonial and foreign invasion by the European countries.

242 Tarāzī, Tārīkh al-șaḥāfa al-'arabiyya, pp. 206, 240, 314; Baladiyyat Ṭarābulis fì mä'at 'ām 1286/1391H-1870/1970M, p. 416.

243 Āarībī, Wathā'iq al-Sarāya al-Hamrā, p. 47. 
